\title{
Class-Based Affirmative Action $\dagger$
}

\author{
Richard D. Kahlenberg $\ddagger$
}

\section{INTRODUCTION}

In recent years, the case law governing affirmative action programs has shifted significantly, making race and ethnic preferences much more difficult to sustain. Further judicial curtailment of race-conscious programs may be in the offing.

Partly in response to this judicial trend, and as a prelude to the 1996 presidential election, the top officials of the two major political parties have taken strikingly different postures on the future of racebased affirmative action. President Bill Clinton argues that we should "mend" rather than "end" affirmative action, though a close analysis of his reasoning suggests that his administration will aggressively defend virtually all affirmative action programs. Republican presidential candidate Robert Dole, by contrast, has backed legislation and an initiative to end publicly sponsored racial preferences.

These stark alternatives-ending public affirmative action, or defending it to the fullest-fail to address the strong moral, legal, and political dilemmas posed in the affirmative action debate. There are, and always have been, valid, principled arguments both for and against affirmative action programs. As John Hart Ely noted more than twenty years ago, "I have trouble understanding the place of righteous indignation on either side of this wrenching moral issue."1

But there is a way to reconcile the best arguments for and against race- and gender-based remedies. This alternative approach recognizes the very real legacy of discrimination, but also acknowledges that there are better, more productive ways of addressing that legacy than through the use of racial preferences. This approach would provide preferences in education, employment, and government contracting based on class

$\dagger$ From the book The Remedy by Richard D. Kahlenberg. Copyright (C 1996 by Richard D. Kahlenberg. Reprinted by arrangement with BasicBooks, a division of HarperCollins Publishers, Inc.

‡ Fellow, Center for National Policy, Washington, D.C. A.B., Harvard College, 1985. J.D., Harvard Law School, 1989. Mr. Kahlenberg has been a visiting associate professor of law at George Washington University National Law Center, and a legislative assistant to Senator Charles S. Robb. He is also the author of Broken Conrract: A Memorr of Harvard Law School (1992).

1. John H. Ely, The Constitutionality of Reverse Racial Discrimination, 41 U. CH. L. REv. 723, 723 (1974). 
or socio-economic status, rather than race or gender-implicitly addressing the current-day legacy of past discrimination without resorting to the toxic remedy of biological preference.

Part I of this Article reviews the shift in the legal landscape surrounding race-based affirmative action, with a particular focus on the broad significance of the U.S. Supreme Court's decision in Adarand Constructors, Inc. v. Pena. ${ }^{2}$ Part II analyzes the responses of the leading figures of the two major political parties: President Clinton's ninety-six-page Affirmative Action Review, ${ }^{3}$ and his widely-publicized July 19, 1995 address on affirmative action at the National Archives Building in Washington, D.C.; and former Senator Dole's "Equal Opportunity Act of 1995,"'s which would repeal federal racial preferences. Finally, Part III proposes a class-based alternative to these two flawed approaches, building the moral, political, and legal case for a system of class-based affirmative action, and explaining how such a system might work in practice.

Current Law On AfFirmative Action: The Significance Of AdARAND

Race-based affirmative action is losing support in the courts. While the Supreme Court has been edging away from affirmative action for a number of years, its recent decision in Adarand nay prove devastating. The Adarand Court held that federal race-conscious decision making should be subject to strict scrutiny. This standard, previously used to judge Jim Crow legislation, requires that a race-based affirmative action program be narrowly tailored to serve a compelling government purpose. ${ }^{6}$ Adarand explicitly overruled the Court's earlier ruling in Metro Broadcasting, Inc. v. $F C C^{7}$-which had held federal affirmative action programs to an "intermediate" level of scrutiny-and thus called into question many federal affirmative action efforts. ${ }^{8}$

2. 1I5 S. Ct. 2097 (1995).

3. Affirmative Action Review: Report To The President (1995) [hereinafter AfFirmative Action Review]. I also review the Justice Department's Memorandum on the implications of Adarand. Memorandum from Walter Dellinger, Assistant Attomey General, Office of Legal Counsel, U.S. Dep't of Justice, to General Counsels (June 28, 1995) [hereinafter Memorandum to General Counsels], reprinted in AFFiRMative Action Review, supra, app. B.

4. Remarks at the National Archives and Records Administration, 31 WEEKLY COMP. Pres. Docs. I255 (July 19, 1995) [hereinafter Remarks], available in LEXIS, Exec Library, Presdc File.

5. S. 1085, 104th Cong., 1st Sess. (1995). The House companion is H.R. 2128, 104th Cong., 1st Sess. (1995).

6. Adarand, $115 \mathrm{~S} . \mathrm{Ct}$. at 2113.

7. 497 U.S. 547 (1990), overruled in part by Adarand, 115 S. Ct. at 2097.

8. Adarand, 115 S. Ct. at 2113. 
Proponents of affirmative action try to downplay Adarand's significance, saying it applies only to remedial programs involving governinent contracting, and not to forward-looking "diversity" programs, private programs, or the educational and einployment spheres. ${ }^{9}$ And, they say, strict scrutiny is not always fatal; indeed, the Court did not actually strike down the rule at issue-a $10 \%$ "bonus" for federal contractors who subcontracted to minority-owned companies-but only remanded the case for application of strict scrutiny. ${ }^{10}$

But, in fact, the decision is likely to have a ripple effect that reaches nonremedial programs, private programs, and programs involving education and employenent. ${ }^{11}$

\section{A. Strict Scrutiny}

Adarand represents the first time that a majority of the Supreme Court has applied strict scrutiny to a federal affirmative action program. ${ }^{12}$ The question now becomes: What will strict scrutiny mean for such programs? For remedial programs, what evidence of past discrimination is required? Can any nonremedial, diversity-enhancing programs survive strict scrutiny?

Proponents of affirmative action point out that only two JusticesScalia and Thomas-said that racial preference is never permissible. And proponents have understandably made much of Justice $O^{\prime}$ Connor's statement that strict scrutiny does not mean the end of affirmative action. O'Connor wrote:

[W] wish to dispel the notion that strict scrutiny is "strict in theory, but fatal in fact." The unhappy persistence of both the practice and the lingering effects of racial discrimination against minority groups in this country is an unfortunate reality, and governinent is not disqualified from acting in response to it. ${ }^{13}$

But it is instructive to read this statement in context. In the very next sentence, O'Connor cites United States v. Paradise ${ }^{14}$ as the kind of case where racial preferences are justified. O'Connor writes: "As recently as 1987 , for example, every Justice of this Court agreed that the

9. Memorandum to General Counsels, supra note 3 , at 2 .

10. Adarand, $115 \mathrm{~S}$. Ct. at 2118.

11. The short-term survival of the contracting program should be of little significance; indeed, the Adarand case may prove to be the mirror opposite of the Supreme Court's landmark decision in Regents of the Univ. of Cal. v. Bakke, 438 U.S. 265 (1978). Whereas in Bakke the Court ordered the white plaintiff immediate relief but endorsed the broad rule that race may be a plus factor in admissions, in Adarand the Court did not immediately invalidate the contested procedure, but did lay down a broader rule of strict scrutiny that calls into question the vast majority of federal affirmative action efforts.

12. Adarand, 115 S. Ct. at 2113,2117 ; see also id. at 2126-27 (Stevens, J., dissenting).

13. Id. at 2117 (citation omitted).

14. 480 U.S. 149 (1987). 
Alabama Department of Public Safety's 'pervasive, systematic, and obstinate discriminatory conduct' justified a narrowly tailored race-based remedy."15

Paradise is the last case proponents of affirmative action would want cited as an example of what passes constitutional muster. As Reagan's Solicitor General Charles Fried has written, the case involved "horrible facts."16 In 1972, a District Court found that the Alabama Department of Public Safety had "engaged in a blatant and continuous pattern and practice of discrimination," and noted that "in the thirtyseven-year history of the patrol there has never been a black trooper."17 When the District Court imposed a hiring and promoting order to remedy past discrimination, the Department engaged in what even the Paradise dissenters termed "reprehensible" recalcitrance in complying with the consent decree. ${ }^{18}$ (Even then, however, four members of the Court felt the hiring and promoting remedy was not narrowly tailored.) $)^{19}$

In other words, in the very section of her Adarand opinion where O'Connor seeks to reassure liberals that strict scrutiny is not necessarily fatal, she sends a second signal that such scrutiny usually is deadly, except in rare cases of repeated and egregious discrimination like that found in Paradise. Assistant Attorney General Walter Dellinger downplays O'Connor's citation to Paradise, noting that in applying strict scrutiny to state-sponsored affirmative action following the Court's decision in City of Richmond v. J.A. Croson Co. ${ }^{20}$ a number of lower courts have been satisfied by a predicate of discrimination that does not rise to the level found in Paradise. ${ }^{21}$ But, of course, these lower courts are not the ultimate arbiters of the strict scrutiny standard. As a practical matter, for the moment Justice O'Connor is. ${ }^{22}$ And in the Croson case, O'Connor laid out what Justice Marshall called a "daunting standard":23 O'Connor said that racial preference schemes would be permissible only "[i]n the extreme case." ${ }^{24}$ Civil rights advocates William Taylor and Susan Liss wrote in 1992 that the Croson evidentiary stan-

15. Adarand, 115 S. Ct. at 2117 (quoting United States v. Paradise, 480 U.S. 149, 167 (1987)).

16. Charles Fried, Order and law: arguing the Reagan Revolution -A FIRSTHAND ACCOUNT 117 (1991).

17. NAACP v. Allen, 340 F. Supp. 703, 705 (M.D. Ala. 1972), cited in Paradise, 480 U.S. at 154.

18. Paradise, 480 U.S. at 201 (O'Connor, J., dissenting).

19. Id. at 196 (White, J., dissenting); id. at 196-201 (O'Connor, J., dissenting).

20. 488 U.S. 469 (1989).

21. Memorandum to General Counsels, supra note 3, at 12.

22. Justice $O^{\prime}$ Connor has cast the swing vote, and authored the majority opinion, in sevcral recent race cases. See, e.g., Adarand Constructors, Inc. v. Pena, 115 S. C. 2097 (1995); Shaw v. Reno, 113 S. Ct. 2816 (1993); City of Richmond v. J.A. Croson Co., 483 U.S. 469 (1989).

23. Croson, 488 U.S. at 555 (Marshall, J., dissenting).

24. Id. at 509. 
dard "may be nearly impossible for most state and local governments to meet."25 This is already a far cry from the standard, urged by Justice Marshall in Bakke, that societal discrimination should suffice as a basis for affirmative action. ${ }^{26}$ And as cases of egregious discrimination dissipate over time, this factual predicate will become increasingly difficult to establish.

\section{B. Nonremedial Programs}

Adarand also may spell trouble for nonremedial and nonfederal affirmative action programs. "Forward-looking" or "diversity" justifications for racial preference are particularly endangered. Justice Stevens, the Court's primary champion of the diversity theory, is technically correct that Adarand overturned Metro Broadcasting only with respect to its holding that federal affirmative action programs are subject to intermediate scrutiny. ${ }^{27}$ Adarand says nothing explicit about whether the forward-looking rationale employed by the FCC in Metrothe promotion of diversity in broadcasting-is still a valid justification for racial preferences. There are, however, implicit negative signals.

First, raising the standard of review obviously spells difficulty for any racial preference system, including those justified with forwardlooking rationales. Even if a majority of the Court affirmed Metro Broadcasting's holding that the FCC has an "important" government mterest in promoting broadcast diversity, that would not satisfy the Court's new requirement that the government purpose be "compelling." 28

Second, Adarand seems to solidify Justice O'Connor's growing skepticism about the diversity rationale for racial preference. Ten years ago, it appeared that Justice O'Connor might be sympathetic to the diversity argument. She indicated in Wygant v. Jackson Board of Education that promoting diversity among a public school faculty might serve as a sufficient rationale for racial preferences. ${ }^{29}$ Since then, however,

25. William L. Taylor \& Susan M. Liss, Affirmative Action in the 1990s: Staying the Course, ANnals AM. ACad. Pol. \& Soc. Sci., Sept. 1992, at 30, 35. Liss happens to be one of the central authors of the President's Review. See Affirmative Action Review, supra note 3.

26. 438 U.S. at 396 (Marshall, J.). The Clinton Administration concedes that societal discrimination is insufficient, thougl even here, representatives hedge, saying that "reinedies for vague societal discrimination" "probably" won't suffice as a compelling interest. Christopher Edley Jr., The Road to Clinton's Big Speech, WASH. Post, July 23, 1995, at C1, C2.

27. Adarand, 115 S. Ct. at 2127-28 (Stevens, J., dissenting).

28. While Walter Dellinger and other proponents of affirmative action have clung to the tantalizing notion that $\S 5$ of the Fourteenth Amendment may give special powers to Congress to remedy violations of the Fourteenth Amendment, Dellinger himself questions whether "the same degree of deference would be accorded to nonremedial legislation." Memorandum to General Counsels, supra note 3 , at 33 .

29. 476 U.S. 267, 288 (1986) (O'Connor, J.). Justice Stevens pointedly reminded Justice O'Connor of this previous opinion in Adarand, 115 S. Ct. at 2127 (Stevens, J., dissenting). 
$\mathrm{O}^{\prime}$ Connor has backed away from that opinion. ${ }^{30}$ In Croson, Justice $\mathrm{O}^{\prime}$ Connor wrote for the Court, "Classifications based on race carry a danger of stigmatic harm. Unless they are strictly reserved for remedial settings, they may in fact promote notions of racial inferiority and lead to a politics of racial hostility."31 And in Metro Broadcasting, Justice O'Connor stated flatly, "Modern equal protection doctrine has recognized only one such [compelling] interest: remedying the effects of racial discrimination. The mterest in increasing the diversity of broadcast viewpoints is clearly not a compelling imterest. It is simply too amorphous, too insubstantial, and too unrelated to any legitimate basis for employing racial classifications." 32 In Adarand, $\mathrm{O}^{\prime}$ Connor suggested that the need to respond to "[t]he unhappy persistence of both the practice and the lingering effects of racial discrimination"33 might provide a compelling governmental purpose necessary to satisfy strict scrutiny. She omitted any reference to promoting diversity, providing further confirmation of her evolution from Wygant to Metro Broadcasting.

Third, it may be significant that two of the four dissenters in Adarand chose not to endorse explicitly the diversity rationale for racial preference. Only Justice Ginsburg joined Justice Stevens' lead dissent, which includes a salute to the diversity argument for preferences. While much has been made of the split among the majority (between the absolutists Thomas and Scalia, and the moderates, O'Connor, Kennedy, and Rehnquist), the split between Breyer and Souter on one hand, and Stevens and Ginsburg on the other, may be of equal significance. Justice Stevens goes out of his way to endorse the "future benefits" rationale for affirmative action, even though the issue is not posed directly by the case. "What truly distmguishes Metro Broadcasting from our other affirmative-action precedents," he writes, "is the distinctive goal of the federal program in that case. Instead of merely seeking to remedy past discrimination, the FCC program was intended to achieve future benefits in the form of broadcast diversity." 34 The separate dissents of Souter-Ginsburg-Breyer and Ginsburg-Breyer make no similar en-

30. See Fried, supra note 16 , at 127-28.

31. Croson, 488 U.S. at 493. Writing in concurrence in Croson, Justice Stevens said he did "not agree with the premise that seems to underlie today's decision ... that a governmental decision that rests on a racial classification is never permissible except as a remedy for a past wrong." Id. at 511 (Stevens, J., concurring).

32. Metro Broadcasting, Inc. v. FCC, 497 U.S. 547, 612 (1990) (O'Connor, J., dissenting). In his majority opinion, Justice Brennan noted the shift from $0^{\prime}$ Connor's previous position in Wygant. Id. at $568 \mathrm{n} .15$.

33. Adarand, $115 \mathrm{~S} . \mathrm{Ct}$ at 2117.

34. Id. at 2127 (Stevens, J., dissenting). 
dorsement of future-oriented rationales for affirmative action, and, if anything, distance themselves from that rationale. ${ }^{35}$

But even if Justices Souter and Breyer turn out to be enthusiasts for the diversity rationale for preference, the Court as currently constituted is unlikely to find that diversity provides the compelling state interest needed to satisfy the strict scrutiny test for government programs. The five-to-four decision in Metro Broadcasting is surely the high-water mark for diversity as a justification for racial preference. Since the 1990 decision, four of the five Justices in the Metro majority have retired, leaving Justice Stevens as the only sure pro-diversity vote. The four Metro dissenters-Justices O'Connor, Kennedy, Scalia, and Rehnquist-remain, and they will surely be joined by Justice Thomas in opposition to diversity-based affirmative action programs. Thomas has been opposed to most forms of racial preference, but is particularly opposed to the diversity rationale, which presumes, in the aggregate, that people of color have a certain viewpoint. ${ }^{36}$ Even Sheila Foster, a strong proponent of the diversity rationale, concedes, "[I]t is unlikely, given the current makeup of the Court, that the diversity rationale will survive in equal protection jurisprudence." 37 Where Metro Broadcasting was once hailed as an open door to broader application of the diversity rationale, it now appears clear that the rationale has very limited applicability beyond the higher education arena. ${ }^{38}$

35. Justices Souter, Ginsburg, and Breyer implicitly distance themselves from forward-looking considerations to the extent that they emphasize that part of what makes the imposition of a burden on innocent whites reasonable is the "temporary" nature of affirmative action programs. Id. at 2133-34. The remedial argument for affirmative action has a built-in time limit, since the legacy of discrimination will dissipate over time. The diversity rationale, by contrast, justifies preferences so long as racial imbalances occur, no matter their source. Thomas Sowell has noted that racial imbalances have existed throughout history and across societies. In some cases, he notes, groups that are overrepresented are themselves the victims of discrimination. This suggests that some racial imbalances are likely to occur even after the legacy of discrimination disappears. See, e.g., THomas Sowell, Preferential Policies: AN International Perspective 88-89 (1990) [hereinafter Sowell, Preferential Policies]; Thomas Sowell, Civil Rights: Rhetoric or Reality? 2021 (1984) [hereinafter Sowell, Civil RIGHTS]. Accordingly, the diversity rationale is likely to make affirmative action more or less a permanent fixture. This is hard to reconcile with Souter, Ginsburg, and Breyer's embrace of temporary remedies.

36. Even after Metro Broadcasting upheld the FCC's racial preference programs, Thomas, as a D.C. Circuit Judge, voted to strike down a similar preference for women. Lamprecht v. FCC, 958 F.2d 382 (D.C. Cir. 1992).

37. Sheila Foster, Difference and Equality: A Critical Assessment of the Concept of "Diversity," 1993 WIS. L. REv. 105, 109.

38. For an example of the high aspirations held by proponents of affirmative action following the Metro Broadcasting decision, see Patricia J. Williams, Comment, Metro Broadcasting, Inc. v. FCC: Regrouping in Singular Times, 104 HaRv. L. REv. 525 (1990). But the wording of Justice Powell's opinion in Bakke was carefully circumscribed: "[T] he interest of diversity is compelling in the context of a university's admissions program...." Regents of the Univ. of Cal. v. Bakke, 438 U.S. 265, 314 (1978). During deliberations over the Bakke case, Powell emphasized in a letter to Justice Brennan that "the judgment itself does not go beyond permissible use of race in the context of achieving a diverse student body at a state university." BERNARD SCHWARTZ, BEHIND BAKKE: 


\section{The Viability of Bakke}

The more interesting question is whether Bakke itself will survive. Beyond its application to remedial, federal affirmative action programs, Adarand also demonstrates that a majority of the Supreme Court is willing explicitly to overrule affirmative action precedents. The Adarand Court did not attempt to distinguish or reconcile Metro Broadcasting; it simply and matter-of-factly overruled it. ${ }^{39}$

What does this mean for Bakke, which for more than twenty years has stood for the proposition that furthering diversity in higher education is a sufficient justification for some racial preferences? Although it is impossible to know for sure, Justice O'Connor's discussion of precedent in Adarand is instructive. In Part III-C of the opinion, Justice O'Connor lays out the difference between Metro Broadcasting (which she is willing to overrule) and Roe v. Wade ${ }^{40}$ which she had refused to overrule in Planned Parenthood v. Casey. ${ }^{41}$ Roe, O'Connor explained, is "a long-established precedent that has become integrated into the fabric of the law."

The question then becomes: Is Bakke like Metro Broadcasting or does it have the "super-precedential" value of Roe? Certain scholars, such as Yale law professor Akhil Amar, contend that Bakke most resembles Roe: "Bakke is arguably more like Roe and should stand even after the less important Metro Broadcasting is tossed out." ${ }^{\text {"43 }}$

But there are strong reasons to doubt that Bakke carries the same precedential value as Roe. First, Bakke is not "integrated into the fabric of the law" in the same way as Roe. ${ }^{44}$ Questions related to Roe have been continually litigated and relitigated in subsequent years; by contrast, there have been no Supreme Court decisions reaffirming Bakke's holding with respect to affirmative action in higher education. Furthermore, while Bakke has enjoyed greater longevity than Metro Broadcasting, and might therefore be thought to carry greater weight, it is

Affirmative Action and the Supreme Court 139-40 (1988). In Wygant, Powell himself put the brakes on forward-looking theories for preferences, noting that the role model justification has "no logical stopping point." Wygant v. Jackson Bd. of Educ., 476 U.S. 267, 275 (1986). At the time Metro Broadcasting was handed down, Charles Fried argued that the Supreme Court had overextended Bakke. "[A]nalogizing the FCC to the governing body of a university, protected by the ancient value of academic freedom, is almost derisory," he wrote. Charles Fried, Comment, Metro Broadcasting, Inc. v. FCC: Two Concepts of Equality, 104 HARv. L. REv. 107, 113 (1990).

39. Adarand, $115 \mathrm{~S}$. Ct. at 2113.

40. 410 U.S. 113 (1973).

41. 112 S. Ct. 2791 (1992). Justices Scalia, Thomas, and Rehnquist chose not to join Part 1II-C of Adarand, underlining their earlier willingness to overrule Roe, and presumably their willingness to overrule Bakke.

42. Adarand, $115 \mathrm{~S}$. Ct. at 2116.

43. Akhil Amar \& Neal Katyal, School Colors, New Republic, July 17 \& 24, 1995, at 24, 24.

44. Adarand, 115 S. Ct. at 2116. 
important to note that the Adarand Court also undercut Fullilove v. Klutznick ${ }^{45}$ - a case decided just two years after Bakke. Fullilove had been read by many observers to apply a more lenient standard of review to congressional affirmative action efforts than to those undertaken by the states, and the Adarand Court had no qualms about disposing of that case. ${ }^{46}$

Second, the Court's fractured four-one-four decision in Bakke is much easier to dismiss than the convincing seven-to-two margin in Roe. Indeed, even the four Justices who joined Justice Powell in providing five votes for the proposition that race can be a factor in university admissions distanced themselves from the diversity rationale for preferences. Justice Brennan wrote that the "central meaning" of the Bakke opinion was that government may take steps to remedy past racial prejudice when proper findings have been made, ${ }^{47}$ and endorsed the diversity justification "at least so long as the use of race to achieve an integrated student body is necessitated by the lingering effects of past discrimination." 48 In fact, Justice Powell's praise for the Harvard plan's use of race as one factor to achieve diversity was itself dicta, since the question at hand was whether the University of California at Davis system was lawful and constitutional..$^{49}$

Third, legal realists might note that to the extent the Court follows election returns, there is a stark divide between Bakke and Roe. Public opinion opposes racial preferences in college admissions by nearly a two-to-one margin. ${ }^{50}$ By contrast, the central holding of Roe is generally accepted by the American people. ${ }^{51}$

At least one federal circuit court has suggested that the Supreme Court's recent decisions call Bakke into question. In Hopwood $v$. Texas, ${ }^{52}$ a March 1996 decision, the Fifth Circuit invalidated a University

45. 448 U.S. 448 (1980).

46. Adarand, $115 \mathrm{~S}$. C. at 2117 ("[T]o the extent (if any) that Fullilove held federal racial classifications to be subject to a less rigorous standard, it is no longer controlling.")

47. Bakke, 438 U.S. at 325 (Brennan, White, Marshall, and Blackmun, JJ., concurring in part and dissenting in part).

48. Id. at $326 \mathrm{n} .1$.

49. Justice Stevens emphasized that "the question whether race can ever be used as a factor in an admissions decision is not an issue in this case, and that discussion of that issue is inappropriate." Id. at 411 (Stevens, J., concurring in part and dissenting in part).

50. See, e.g., Rick Wartzman, Clinton Is Still Struggling to Get Message Across To 'Angry White Males' Who Have Tuned Out, Wall ST. J., Jan. 24, 1995, at A24 (citing Wall Street Journal/NBC News Poll indicating that by a $61 \%$ to $32 \%$ margin Americans favor "eliminating affirmative action based on race or gender in deciding admissions to state universities, hiring for government jobs and awarding federal contracts").

51. See, e.g., Ronald G. Shafer, Washington Wire, Wall ST. J., Dec. 8, 1995, at A1 (citing December 1995 Wall Street Journal/NBC poll for the proposition that $60 \%$ of Americans believe abortion should be legal, while only $10 \%$ think abortion should be illegal in all cases).

52. 78 F.3d 932 (5th Cir.), cert. denied, 116 S. Ct. 2580 (1996). 
of Texas program that employed racial preferences in law school admissions. The circuit court noted the Supreme Court's apparent, recent rejection of the diversity rationale for preferences. ${ }^{53}$

In the future, short of overturning Bakke, the Court might choose to enforce rigorously its limiting provisions. In Bakke, Justice Powell argued that a university's race-plus plan operating as "the functional equivalent of a quota system" could be struck down on a showing of bad faith. ${ }^{54}$ Powell also said preferences could be used to tip the balance in admissions, ${ }^{55}$ so the Court might strike down preferential policies that result in enormous disparities in SAT scores among racial groups in the freshman class. ${ }^{56}$ Likewise, the Court might enforce the strict scrutiny requirement that race-neutral methods be employed to achieve racial diversity where such methods are effective. ${ }^{57}$

\section{II}

\section{Political Responses to the Changing}

\section{AfFiRmative Action Debate}

In response to Adarand and to the larger public debate over affirmative action, the two major 1996 presidential candidates have outlined divergent positions on affirmative action. President Clinton says he proposes to "mend" affirmative action, though his suggested alterations are cosmetic; Robert Dole proposes to "end" it, at least insofar as the federal government is involved. Neither policy is satisfactory.

\section{A. President Clinton's Four Standards to "Mend" (Read: Defend) Af- firmative Action}

On March 7, 1995, President Clinton ordered a review of all federal affirmative action programs. ${ }^{58}$ More than four months later, after much internal debate, the President released the administration's Affirmative Action Review and publicly set forth his position in a speech at the Na-

53. Id. at 942,945 . On appeal, the United States Supreme Court denied review. Texas v. Hopwood, No. 95-1773, 1996 U.S. LEXIS 4267 (1996). Justice Ginsburg, in a concurring opinion, noted that the petitioners challenged the rationale by which the lower court invalidated the University of Texas' admissions program, and that the program "has long since been discontinued." $I d$. at *1. Ginsburg stated that "we must await a final judgment on a program genuinely in controversy before addressing the important question raised in this petition." Id. at *2.

54. Bakke, 438 U.S. at 318-19. Powell argued, however, that "good faith would be presumed in the absence of a showing to the contrary in the manner permitted by our cases." Id.

55. Id. at 316-18.

56. The size of the disparity in scores is often not made public, but in the major litigated cases, preferences have been much larger than the phrase "tipping the balance" would suggest. See, e.g., DeFunis v. Odegaard, 416 U.S. 312, 324-25 (1974); Bakke, 438 U.S. at 276-77; Hopwood, 78 F.3d at 937. But for the difficulty of enforcing Powell's distinction, see infra text accompanying notes 77-85.

57. City of Richmond v. J.A. Croson Co., 488 U.S. 469, 507 (1989).

58. Affirmative Action Review, supra note 3, at 1. 
tional Archives. The President argued that affirmative action should be "mended" rather than "ended." $59 \mathrm{He}$ announced four core principles by which affirmative action programs should be judged, and directed all federal agencies to abide by those principles. "The policy principles are that any program must be eliminated or reformed if it:

(a) creates a quota;

(b) creates preferences for unqualified individuals;

(c) creates reverse discrimination; or

(d) continues even after its equal opportunity purposes have been achieved." ${ }^{60}$

The President positioned himself as an affirmative action "moderate," even suggesting that his four principles go further than Adarand in reining in excesses. ${ }^{61}$ In fact, Clinton's principles rule out only a small subset of what Adarand forbids, and his attempt to "mend" affirmative action does little to address the very real concerns of those opposed to current programs.

Following the announcement of the Adarand decision, Clinton tried to downplay its significance in three ways. First, Clinton recharacterized the five-to-four decision for strict scrutimy as a seven-to-two decision agamst the absolutist position staked out by Justices Thomas and Scalia that racial preferences are never permissible. ${ }^{62}$ Seven of nine Justices, Clinton argued, "actually reaffirmed the need for affirmative action." ${ }^{63}$ In making this argument, Clinton had the help of some conservative commentators, like columnist George F. Will, who were disappointed that the Court had not simply declared government racial preference programs unconstitutional per $s e .{ }^{64}$ Yet, both Clinton and Will misconstrued the siguificance of the decision: even though only two Justices said racial preferences are never justified, five said almost never.

59. Remarks, supra note 4.

60. Memorandum for Heads of Executive Departments and Agencies (July 19, 1995) [hereinafter Memorandum for Dep't Heads], reprinted in AfFirmative Action Review, supra note 3, app. A; see also Remarks, supra note 4 ("No quotas in theory or practice; no illegal discrimination of any kind, including reverse discrimination; no preference for people who are not qualified for any job or other opportunity; and as soon as a program has succeeded, it must be retired.").

61. See infra text accompanying notes 67-69.

62. Scalia and Thomas do of course concede that actual victims of discrimination may be made whole, but that practice does not constitute "affirmative action" as the term is commonly understood. See, e.g., Adarand, 115 S. Ct. at 2118 (Scalia, J., concurring).

63. Remarks, supra note 4; see also Edley, supra note 26, at C2. Walter Dellinger's memo is generally less subject to spin, but even he twice repeats the 7-2 argument. Memorandum to General Counsels, supra note 3 , at 1,6 .

64. See, e.g., George F. Will, Affirmative Action: The Court's Murky Ruling .... WASH. POST, June 14, 1995, at A25 (saying the opinion uses "hairsplitting" reasoning and questioning the distinction between intermediate and strict scrutiny: "By what standard is the 'compelling' to be distinguished from the merely 'significant'?"). 
Second, despite the Solicitor General's brief in Adarand, which argued strenuously in favor of the federal program at issue, the Administration claimed some general sense of agreement with the thrust of the Court's decision. Harvard Law Professor Christopher Edley Jr., who cochaired the President's affirmative action review, said that the review and the Adarand Court were both moving "in a not unrelated direction." Following the decision, Clinton said, "I have always believed that affirmative action is needed to remedy discrimination and to create a more inclusive society that truly provides opportunity. The Court's opinion ... is not inconsistent with that view."66

Third, the Clinton administration actually suggested that the President's four standards of fairness for affirmative action programs were tougher and more stringent than the guidelines laid down by the Adarand Court. The President's Affirmative Action Review states, "The Court's decision concerned what is constitutionally permissible, which is a necessary but not sufficient consideration in judging whether a measure is wise public policy." The Affirmative Action Review urges the President to issue a directive that "not only" directs agencies to comply with Adarand, "but also instructs them to apply a set of basic policy principles." ${ }^{68}$ Thus, the President implies that his four policy principles supplement Adarand. ${ }^{69}$ We are to believe that the Court's decision, which Clinton's Justice Department vigorously opposed as too restrictive, is in fact just the starting place for Clinton's more demanding tests of affirmative action. An examination of the four principles shows otherwise.

\section{No Quotas}

Clinton's first principle states that any program that "creates a quota" should be reformed or eliminated. The President does not define the word "quota" in his speech, but the Affirmative Action Review says this: "Quotas are intrinsically rigid, and intrinsically relegate qualifications and other factors to secondary status." embraces the classic distinction between "goals" (flexible) and "quotas" (rigid). ${ }^{11}$ He draws on a distinction between "consideration

65. Edley, supra note 26, at C2.

66. The End of Affirmative Action, New Republic, July 3, 1995, at 7 (editorial).

67. AFFrmative ACTION REViEW, supra note 3, at 6 .

68. Id.

69. See Remarks, supra note 4. ("Today I am directing all our agencies to comply with the Supreme Court's Adarand decision, and also to apply the four standards of faimess to all our affirmative action programs that I have already articulated ...." (emphasis added)).

70. AfFiRmative Action Review, supra note 3, at 4.

71. While Clinton opposes quotas, he favors a "goals and timetables" approach. See, e.g., ld. at 29-39 (describing the efforts of the Department of Labor's Office of Federal Contract Compliance Programs). 
of race, ethnicity, and gender"72 (race as a "factor") and quotas, which require that a fixed number of slots be filled with underrepresented minorities.

This distinction between quotas and race as a factor has been dubbed the "Bakke straddle," after Justice Powell's controlling opinion in Bakke. ${ }^{73}$ Justice Powell wrote that in achieving the compelling purpose of furthering diversity in a student body, race may be used as a "factor" or "plus" in admissions, so long as an actual set-aside or quota is not employed. ${ }^{74}$ Since the U.C. Davis medical school admissions policy at issue set aside sixteen of one hundred slots for minority applicants, the Bakke court voided the plan and ordered that the white plaintiff, Allan Bakke, be admitted. ${ }^{75}$

At the time the decision was handed down, some progressives balked at this limitation. As Terry Eastland and William Bennett have noted, when the Bakke decision was first announced, a number of commentators on the left were outraged.

* "Bakke-We Lost," blurted the headline in New York City's Amsterdam News.

* Peter Cohn, co-counsel for the regional office of the NAACP in Washington, D.C., said, "I think this is a very sad day in the United States. The Bakke decision represents a step back in time."

* Tyrone Brooks, national field director for the Southern Christian Leadership conference, said, 'I' $m$ very disappointed .... [The ruling] ineans that the incentive to carry out affirmative action will be killed."

* Tom Wicker of the New York Times commented: "The validity and potential of affirmative-action programs may have been seriously, if not fatally, undermined."

* Jose Medina of La Raza, a Chicano political group, said Bakke was a very disappointing decision because in it the Court declared that "the Fourteenth Amendment is no longer for the protection of identifiable minorities but an amendment for the protection of the rights of society as a whole."

* The Reverend Jesse Jackson called the decision a "devastating blow to our civil-rights struggle" and urged "inassive street demonstrations" to "educate Americans as to our displeasure."

* University of Pennsylvania law professor Ralph Smith said that the Court's judgment could be used to attack affirmative action, and that was something "a society that purports to cherish domestic tranquility ought to avoid."

72. Memorandum for Dep't Heads, supra note 60, at 1 .

73. 438 U.S. 265 (1978).

74. Id. at 317-18 (Powell, J.).

75. Id. at 320 . 
* Congressman Ron Dellums of Michigan [sic] regarded Bakke as a "racist decision by the Nixon court"; he called on "all people of good will" to denounce it.

* Professor Kenneth Tollett of Howard University said the decision was "a hammer in the solar plexus."

But a number of more sophisticated commentators realized that there was less substance in Powell's distinction than first appeared. On the Court itself, none of the other justices appeared to believe that there was a substantive difference between Harvard's race-plus system and Davis' quota system. Justice Brennan argued, "There is no sensible, and certainly no constitutional, distinction between, for example, adding a set number of points to the admissions rating of disadvantaged minority applicants as an expression of the preference with the expectation that this will result in the admission of an approximately determined number of qualified minority applicants and setting a fixed number of places for such applicants as was done here." Ju Justice Blackmun underlined his skepticism about the quota/race-plus distinction in a separate concurrence, noting. "The cynical, of course, may say that under a program such as Harvard's one may accomplish covertly what Davis concedes it does openly." ${ }^{.78}$ Justices Stevens, Rehnquist, and Stewart, and Chief Justice Burger, who declared the U.C. Davis program illegal, did not speak directly to the issue of preferences versus quotas, but their adherence to the "plain language" of Title VI-outlawing discrimination based on race-suggests they did not see a difference between racial preferences and quotas. ${ }^{79}$

Subsequent experience with the Bakke straddle has validated such skepticism about any real difference between a race-plus and a quota system. Most universities have learned to live quite well with the "prohibition" against quotas. Harvard's flexible race-plus system, specifically lauded by Justice Powell, has yielded a remarkably consistent percentage of African-American students year in and year out. ${ }^{80}$ At the U.C. Davis Law School, minority admissions shot up from thirteen percent in 1969 to forty-two percent in 1972, without an increase in minority scores, but because the law school did not state a quota the way

76. TERry Eastland \& William J. BenNetT, Counting by Race: Equality from the Founding FATHERS TO BAKKE AND WEBER 172-73 (1979) [asterisks separating the various statements added].

77. Bakke, 438 U.S. at 378 (Brennan, White, Marshall, and Blackmun, JJ.).

78. Id at 406 (Blackmun, J.).

79. Id at 412 (Stevens, J.).

80. Alan M. Dershowitz \& Laura Hanft, Affirmative Action and the Harvard College DiversityDiscretion Model: Paradigm or Pretext?, 1 CARDozo L. Rev. 379, 382 n.13 (1979) (noting that the pereentage of black students at Harvard more than doubled, from $3 \%$ to $7 \%$ in the early 1970 s, and has remained remarkably constant since then). 
the medical school had, the program was found to pass muster under Bakke. ${ }^{81}$

Indeed, federal guidelines to universities, published in 1979 by the Department of Health, Education and Welfare, stated that while quotas are illegal, institutions may "[e]stablish and pursue numerical goals to achieve the racial and ethnic composition of the student body it seeks." 82 And when the Bush Administration issued guidelines on minority scholarships, Education Secretary Lamar Alexander went out of his way to advertise that the ruling, which banned certain race-exclusive scholarships but allowed race to be used as a plus factor, was in practice meaningless: "A college president with a warm heart and a little common sense and a minimum amount of good legal advice can make a special effort to grant scholarships to minority students and can use financial aid to create diversity on his campus." 83 The Education Department's Office of Civil Rights did not find a single violation of Title VI in the affirmative action admission procedures of a university until 1992.84 If anything, commentators on the left and the right agree, the

81. See DeRonde v. Regents of the Univ. of Cal., 625 P.2d 220, 234 (Cal. 1981) (Mosk, J., dissenting), cert. denied, 454 U.S. 832 (1981).

82. Nondiscrimination in Federally Assisted Programs; Title VI of the Civil Rights Act of 1964; Policy Interpretation, 44 Fed. Reg. 58,509, 58,511 (1979), cited in Dershowitz \& Hanft, supra note 80, at $381 \mathrm{n} .8$.

83. Kenneth J. Cooper, Limits on Race Scholarships Proposed, WASH. PoST, Dec. 5, 1991, at A3.

84. In 1992, Boalt Hall, the law school at U.C. Berkeley, agreed to void its admissions policy, which went far beyond Harvard's subtle "race-plus" system and violated even the minimal requirement of Bakke to keep up appearances. Between 1978 and 1992, Boalt Hall consistently admitted between $23 \%$ and $27 \%$ of each class from minority groups, which one might suspect to trigger suspicion of a covert quota. But Boalt Hall's pohicy was, in fact, challenged instead for its much more flagrant violation of Bakke. The Education Department found that the law school employed a practice of placing minority candidates into separate tracks, so that minority candidates competed only with members of their own groups (a seeming refinement of the U.C. Davis scheme, which lumped all minorities together). Anthony DePalma, Berkeley Halts Quotas, N.Y. TImEs, Oct. 4, $1992, \S 4$, at 2. The Education Department's investigation was instituted, according to press reports, after an Asian applicant received a letter essentially saying she was on the "Asian waiting list." Dinesh D'Souza, Illiberal Education: The Politics of Race and Sex on Campus 36 (1991). Boalt Hall agreed, without an admission of guilt, to change its policy of "isolating minority applicants from the general pool." DePalma, supra. Herma Hill Kay, dean of the Berkeley law school, said, "We are proud of this policy," and Robert Atwell, president of the American Council on Education, called the decision a "real blow to the efforts to achieve racial diversity." Mary Jordan, Berkeley Law Admission Policy Voided, WAsH. Post, Sept. 29, 1992, at A1. Dean Kay also declared, "We think we can correct these concerns about our program with very minor procedural changes and continue the thrust of our program." How to Be Affirmative but Not Discriminate, LA. Times, Oct. 7, 1992, at B6 (editorial). Incidentally, in 1979, Kay had advocated the outright use of quotas in another context, academic employment. Herma Hill Kay, Commentary: The Need for SelfImposed Quotas in Academic Employment, 1979 WASH. U. LQ. 137. 
discretionary nature of race-plus normally insulates affirmative action programs from attack. ${ }^{85}$

Following the Bakke decision, most proponents of racial preference disavowed quotas, even as they pursued similar ends with more subtle means. Today, virtually no one openly argues for quotas, so Clinton's first limitation carries little real-life significance. By embracing the Bakke straddle, rejected by eight of nine members of the Bakke Court, Clinton merely endorses continued subtlety. Thus, the practical impact of the quota limitation is minimal.

\section{No Preferences for the Unqualified}

Clinton's second principle, closely related to the first, states that preferences should not be given to "the unqualified." .This is an obvious sleight of hand: if few argue for quotas, even fewer argue for preferences for the unqualified. Everyone realizes that advancing a genuinely unqualified applicant does no one any good, least of all the so-called beneficiary. The universe does not divide clearly into qualified and unqualified. The tough question is whether programs will prefer the less qualified over the more qualified or, more sharply, the minimally qualified over the highly qualified. Clinton clearly favors preferences within this range, but obscures this point by coming out against preferences for the unqualified. ${ }^{86}$

\section{No Reverse Discrimination}

Clinton's third limiting principle is that no program should involve "reverse discrimination." Again, the definition is important. The phrase "reverse discrimination" clearly suggests the use of skin color to the disadvantage of whites, rather than to the disadvantage of blacks or other racial minorities. When Clinton says he is opposed to reverse discrimination, the average American may think he is opposed to preferences for people of color and favors only the old, nonpreferential form of affirmative action-broadening the pool of applicants and then making actual hiring decisions on a race-neutral basis. Clinton, however, defines "reverse discrimination" narrowly and quite differently from the way the term is commonly understood: for the President, "reverse discrimination" describes only a racial preference that is actu-

85. See Derrick A. Bell, JR., Race, RaCism AND AMERICAN LAW 657 (3d ed, 1992) ("[A]ny intelligently operated program of admissions that includes minorities should be almost immune from successful legal challenge."); Antonin Scalia, Commentary: The Disease As Cure, 1979 WASH U. LQ. 147, 148 (arguing that a race plus judgment for diversity is "effectively unappealable").

86. See Remarks, supra note 4. 
ally illegal. He says he is opposed to "illegal discrimination of any kind, including reverse discrimination."

This narrow definition of reverse discrimination means that most preferences that negatively affect white applicants will not violate the President's principle. A literal reading of the Civil Rights Act of 1964 would suggest that reverse discrimination is always illegal, since the act prohibits discrimination on the basis of race, color, religion, sex, and national origin..$^{88}$ The Supreme Court, however, has rejected a literal reading of the 1964 Civil Rights Act and has held that racial preferences are perfectly legal in a number of settings. In the university context, "reverse discrimination" as commonly understood is legal under Bakke so long as universities use race as "one factor" to create a more ethnically and racially diverse class. ${ }^{89}$ In private employment settings, "reverse discrimination"-considering skin color or surname as a plus factor-is legal when part of a bona fide affirmative action plan..$^{90}$

Guidelines promulgated by the Equal Employment Opportunity Commission in 1979 demonstrate that "reverse discrimination" would not only be tolerated, but encouraged. The EEOC said that despite the neutral language of Title VII of the 1964 Civil Rights Act, the Act's purpose was "to improve the economic and social conditions of minorities and women by providing equality of opportunity in the work place." $" 11$ Given this purpose, voluntary affirmative action plans that prefer women and minority applicants should not be barred by a literal interpretation of the Act, the Agency urged. If an employer finds it has a racial imbalance in its work force that it concludes is the result of past or present discrimination, affirmative action programs may be established. Significantly, employers may conclude there was discrimination "without any admission or formal finding that the person has violated Title VII, and without regard to whether there exists [sic] arguable defenses to a Title VII action." than the one applied to public-sector affirmative action programs, which

87. Id. at 10. Christopher Edley says that the president means by "reverse discrimination" "what the Supreme Court means," that is to say, unlawful discrimination against whites and males. Edley, supra note 26, at C2.

88. See 42 U.S.C. $\$ 2000$-2(d) (1994). Senator Humphrey, one of the main supporters of Title VII, argued that it "would prohibit preferential treatment for any particular group." See United Steelworkers v. Weber, 443 U.S. 193, 243 (1979) (Rehnquist, J., dissenting) (quoting remarks of Humphrey).

89. Bakke, 438 U.S. at 318 . 197.

90. Johnson v. Transportation Agency, 480 U.S. 616 (1987); United Steelworkers, 443 U.S. at

91. Equal Employment Opportunity Commission, Affirmative Action Guidelines, 44 Fed. Reg. 4422,4426 (1979) [hereinafter Affirmative Action Guidelines].

92. Id. at 4427 . 
must be buttressed by findings of discrimination. ${ }^{93}$ The EEOC guidelines provide:

Affirmative action under these Guidelines may include interim goals or targets. Such interim goals or targets for previously excluded groups may be higher than the percentage of their availability in the work-force so that the long term goal may be met in a reasonable period of time. In order to achieve such interim goals or targets, an einployer may consider race, sex, and/or national origin in inaking selections from among qualified or qualifiable applicants. ${ }^{94}$

If an employer followed its guidelines, the Commission would "issue a determination of no reasonable cause" against reverse discrimination suits filed by white inales.95

In 1979 the Supreme Court upheld these regulations, for the most part, in its 5-2 decision in United Steelworkers v. Weber. ${ }^{96}$ The Court held that employers inay provide preferences "to eliminate manifest racial imbalances in traditionally segregated job categories" so long as the preference plan does not "unnecessarily trammel the interests of the white employees." In particular, the plan must not require the discharge of white workers and their replacement with new hires, create an absolute bar to the advanceinent of white employees, or be permanent in nature. ${ }^{98}$ These limitations have very little teeth. As Clinton's own Solicitor General Drew S. Days III has written, "one is left to conjecture whether any plan would fail this test as long as its avowed purpose was to ameliorate the condition of black workers, and as long as it was structured to bring black representation up to its proportion in the local labor force." 99

93. For a discussion of the differential standards, see George Rutherglen \& Daniel R. Ortiz, Affirmative Action Under the Constitution and Title VII: From Confusion to Convergence, 35 UCLA L REV. 467 (1988).

94. Affirmative Action Guidelines, supra note 91 , at 4425 .

95. Id. at 4429 .

96. 443 U.S. 193 (1979).

97. Id. at $197,208$.

98. Id. at 208. See also Johnson v. Transportation Agency, 480 U.S. 616 (1987).

99. Drew S. Days IIl, Fullilove, 96 YALE LJ. 453, 462 (1987). Days argues: "In brief, the Court in Weber should have required the employer and union to have made a showing of past discrimination." Id. President Clinton would go beyond even the flimsy requirements of Weber and allow employment preferences where no remedial justification is present. The Review argues that in some circumstances, "race- and gender-conscious measures can also be justified by the compelling importance of inclusion." In the employment sphere, race and gender preferences are justified, the Review says, to help create diversity in a "police department," "[t]he military," "major corporations," and among "judges and government policymakers." AFFiRMIATIVE ACTION REVIEW, supra note 3, at 3-4. The underlying theory is that apart from remedial considerations, race will often be a kind of bona fide occupational qualification ("BFOQ"). "A police department will be more effective in protecting and serving its community if its officers are somewhat reflective of the community." Racial and gender imbalances in the military leadership undermines "the cohesion and 
Apparently, then, Clinton's opposition to "reverse discrimination" covers only those rare instances where racial preferences are employed despite a racial balance in the work force, or where an employer refuses to hire a white applicant out of racial animus. ${ }^{100}$ In common parlance, the latter instance is not so much "reverse discrimination" as out-andout discrimination.

\section{Retire when the Job Is Done}

Clinton's final principle-that affirmative action preference programs be retired once they have accomplished their job ${ }^{101}$-also carries little weight. The key to the limitation is the way in which one measures whether the program's "equal opportunity purposes have been achieved."102 Clinton did not specifically define achievement or success in his speech, but it appears that the President will not consider the job done until discrimination is eradicated. Affirmative action, Clinton says, "should be retired when its job is done. I am resolved that that day will come. But the evidence suggests, indeed, screams that that day has not come. The job of ending discrimination in this country is not over."103 This argument for racial preference as a bulwark agamst ongoing discrimination (as opposed to the ongoing legacy of past discrimination) is a new and troubling line of reasoning, which confuses the role of antidiscrimination statutes with affirmative action. ${ }^{104}$ For now, however, it is sufficient to note that any argument that justifies racial preference so long as discrimination exists is an argument for racial preference in perpetuity.

Clinton's four standards of fairness for affirmative action are advertised as a way to help see where affirmative action "[has] worked and where it hasn't." 105 The standards are meant to give substance to the

effectiveness of military units." The same is true of "major corporations." And, finally, "[j]udges and government policymakers must be able to reflect the concerns, aspirations and experiences of the public they serve in order to do their job well and enjoy legitimacy. Id. at 4; see also id. at 52 . None of these rationales has ever been approved by the Supreme Court, and it is not at all clear that even the most enthusiastic supporters of the diversity theory-Justices Stevens and Ginsburg-would go along with all of these justifications. The diversity theory, while popular among academics, ignores the fault line laid down by the Court between education (where the diversity rationale was tentatively accepted in Bakke), 438 U.S. at $311-12$, and employment (where it was essentially rejected in Wygant v. Jackson Bd. of Educ.), 476 U.S. 267, 275 (1986).

100. See, e.g., McDonald v. Santa Fe Trail Transp. Co., 427 U.S. 273 (1976) (invalidating the firing of two white employees accused of theft where a black employee similarly accused was retained).

101. Elsewhere, the President says a program must be retired as soon as it has "succeeded." Remarks, supra note 4.

102. Memorandum for Dep't Heads, supra note 60 , at 1 .

103. Remarks, supra note 4 .

104. See Richard D. Kahlenberg, The Remedy: Class, Race, and AfFirmative Action 153-64 (1996).

105. Remarks, supra note 4. 
President's slogan, "Mend it, but don't end it."106 But nowhere in the speech does Clinton give an example of where a specific program has gone too far. Consider whether the most ardent advocate of racial preference could reasonably disagree with any of the President's limitations. Is there anyone who today will seriously argue for rigid quotas, for preferences for the unqualified, for illegal reverse discrimination, or for continuing affirmative action once the job is done? The question answers itself. ${ }^{107}$

Furthermore, it is not clear that the President even follows his own rather loose guidelines for fairness. It is unclear how serious he is about his opposition to quotas, given his decision early in his administration to place an effectively absolute bar on men for the position of Attorney General. ${ }^{108}$ And it is unclear how serious he was about ensuring that "the effect on nonbeneficiaries" be "sufficiently small and diffuse"109 when he endorsed the Piscataway, New Jersey, School Board's decision to lay off an equally qualified white teacher for reasons of diversity. ${ }^{110}$

Indeed, there is some evidence that the administration knows the real score of Adarand, but is planning to respond to the decision only when its hand is forced. In a widely quoted statement, Assistant Attorney General for Civil Rights Deval Patrick said the Administration would not be "intimidated" by Adarand." It hardly seems an accident that the first two policies that the Administration chose to discontinuethe FCC's diversity preference for personal communications services and the Defense Department's "rule of two"-were the subject of pressure from the outside in the form of litigation. ${ }^{112}$

106. Id.

107. For an alternative interpretation, see BEN J. WATtenberg, VAlues MATter MOST 344 (1995) (arguing that the President may give the standards teeth and try to appear firmer on affirmative action during the general election campaign).

108. Everybody Happy?, EconomisT, Dec. 26, 1992, at 30.

109. AfFirmative Action Review, supra note 3, at 5.

110. Iver Peterson, Justice Department Switches Sides in Racial Case, N.Y. TIMEs, Aug. 14, 1994, at 37, 46. Even strong supporters of affirmative action, such as Kathleen Sullivan, concede the Administration went against established precedent in the Piscataway case. Id. In Wygant, the Court held that even if there were a factual predicate of discrimination justifying racial preferences in hiring, laying off white workers with more seniority was a "burden" which "is too intrusive." 476 U.S. at 283. In his Wygant opinion, Justice White rejected the notion that whites could be fired "to make room for blacks." Id. at 295 (White, J., concurring). See also Firefighters Local Union No. 1784 v. Stotts, 467 U.S. 561, 579 (1984) ("Even when an individual shows that the discriminatory practice has had an impact on him, he is not automatically entitled to have a nonminority employee laid off to make room for him.").

111. Nat Hentoff, ... And Double Talk, WASH. Post, Aug. 9, 1995, at A19.

112. In June 1995, the FCC dropped its preference for minority and female bidders in the auction for wireless communication licenses, earning praise from minority- and female-headed firms, which did not wish to see the auction delayed over affirmative action litigation. Daniel Pearl, Women, Blacks Back FCC Plan to Hold Wireless Auction Without Preferences, WALl ST. J., June 23, 1995, at B6. In October 1995, the Defense Department suspended the "rule of two," previously used to prefer small minority-owned businesses. Under this rule, if at least two small, disadvantaged 


\section{B. Robert Dole's Plan to "End" Affirmative Action}

If President Clinton's approach represents an overly aggressive defense of preferences, what of the position of the opposition? A review of the evidence suggests that presunptive Republican presidential nominee Robert Dole is equally adept at using rhetoric unconnected to the affirmative action policies he advocates. Ultimately, Dole has failed to offer any substantive inethod for achieving the worthwhile goals of affirmative action in a more productive way than current racial preferences do.

\section{The Dole Plan: Abolish Public Preferences}

Robert Dole has not laid out a detailed analysis of affirmative action programs, or even provided a inajor address, as the President has. But it is instructive to look at the Equal Opportunity Act of $1995,{ }^{113}$ which is designed, in the words of its then-Senate sponsor, Bob Dole, to "get the Federal Government out of the group preference business."114 The bill prohibits the federal government from intentionally discriminating against, or granting preferences to, individuals or groups based on "race, color, national origin, or sex ...."115 The measure also prohibits the federal government from requiring or encouraging federal contractors or subcontractors to employ such discrimination or preferences. ${ }^{116}$ As defined by the bill, preference includes, but is not limited to, "any use of a quota, set-aside, numerical goal, timetable, or other numerical objective." The legislation's prohibition does not reach old-style affirmative action (broadening the pool of applicants without providing a preference in decision making). ${ }^{118}$ Nor does the legislation affect historically black colleges and universities, or Indian tribes. ${ }^{119}$

businesses expressed interest in bidding for a contract, only disadvantaged businesses would be allowed to compete for it. The rule was, according to reports, "the only federal set-aside operation under significant federal court challenge." Ann Devroy, Rule Aiding Minority Firms to End, WASF. Post, Oct. 22, 1995, at A1, A6.

113. S. 1085 , supra note 5 .

114. 141 CoNG. Rec. $\$ 10,260$ (July 19, 1995) (statement of Senator Dole).

115. S. 1085 , supra note $5, \S 2(1)$.

116. Id. $\S 2(2)$. In addition, the bill specifies that the Federal Government may not "enter into a consent decree that requires, authorizes, or permits any activity prohibited by paragraph (1) or (2)." Id. $\S 2(3)$. This section might be read to prohibit the federal government from entering into affirmative action consent decrees following a finding of discrimination by the EEOC. Certain civil rights groups have given the bill this broad interpretation. See, e.g., Leadership Conference on Civil Rights, Summary of the Dole/Canady Bill (S.1085/H.R. 2128), at 2. The sponsor of the legislation in the House, Rep. Charles T. Canady, says that is not the intent of the legislation. Title Vll claims are outside the scope of the bill. Interview with Representative Charles T. Canady, in Washington, D.C. (Sept. 20, 1995).

117. S. 1085 , supra note $5, \S 8(2)$.

118. Id. $\S 3$.

119. Id. $\S 4$. 
The California Civil Rights Initiative (CCRI), which backers have placed on the November 1996 ballot in California, takes a tack similar to Dole's and prohibits the state from discriminating against, or granting preferences in favor of, individuals on the basis of race, gender, or national origin. The text reads, in relevant part: "Neither the State of California nor any of its political subdivisions or agents shall use race, sex, color, ethnicity, or national origm as a criterion for either discriminating against, or granting preferential treatment to, any individual or group in the operation of the State's system of public employment, public education, or public contracting." 120

Both the Equal Opportunity Act and the California Civil Rights Initiative have the advantage of simplicity: they adopt the ScaliaThomas position with respect to state action. As Scalia argued in Adarand, "under our Constitution there can be no such thing as either a creditor or a debtor race.... In the eyes of government, we are just one race here. It is American."'121

Both the bill and the initiative, however, underestimate the difficult task of remedying a history of discrimination. The two measures miss the mark, applying a meat axe where a more refined instrument is required.

\section{The Dole Plan Goes Too Far ${ }^{122}$}

Dole's Equal Opportunity Act and the CCRI both go too far in curtailing preference, because the measures would leave unremedied a large and troublesome legacy of discrimination against women and people of color, particularly African Americans. Without doubt, the current, depressed condition of many African Americans reflects in some significant part the legacy of past discrimination. Senator Dole has characterized affirmative action as a response to slavery. ${ }^{123}$ But of course our nation's discrimination against African Americans did not end with the Civil War, and the legacy of more recent discrimination is

120. Assembly Constitutional Amendment No. 2, California Legislature, 1995-96 Regular Session, § 31(a).

121. 115 S. Ct. at $2118-19$.

122. While I argue in this section that the Republican plan goes too far in the public sphere, at the same time it does not go "far enough" in curtailing private preferences. For an explanation of how politics and libertarian principle have combined to create a rhetorical mismatch between Republican policies in the private sector and their color-blind thetoric, see Richard D. Kahlenberg, Bob Dole's Colorblind Injustice; On Affirmative Action, He Caves to Big Business, Wash. Post, June 2,1996 , at $\mathrm{C1}$.

123. R. Jeffrey Smith, GOP Senators Begin Studying Repeal of Affirmative Action, WASH. PosT, Feb. 6, 1995, at A1, A5 (quoting Senator Dole: "Slavery was wrong. But should future generations have to pay for that?") 
powerful. ${ }^{124}$ Nor can the suffering of blacks be easily compared with the suffering of Irish Americans or other ethnic groups. As Justice Marshall noted in Bakke, "The experience of Negroes in America has been different in kind, not just degree, from that of other ethnic groups."125 Without falling into the trap of assuming that all groups would be equally represented in various fields but for discrimination, a rough link can still be drawn between the discrimination against African Americans and their current condition.

Although they are correct in pointing to the downside of racial preferences, both the Equal Opportunity Act and the CCRI fail to remedy the present effects of past discrimination in any creative way. Neither measure presents a positive agenda for addressing the legacy of discrimination. In particular, there is no aggressive call to address past discrimination through class-based preferences for the disadvantaged. ${ }^{126}$ As President Clinton correctly notes, it is "ironic" that those who claim to oppose racial preference because it thwarts equal opportunity are also leading the way to cut Head Start and government-backed college loans. ${ }^{127}$ If the goal is to empower poor and middle-class Americans, Clinton asks, why raise taxes on those families, while at the same time reducing funding for education, job training, and housing programs? Republican rhetoric about color blindness also rings hollow as agencies entrusted with enforcing antidiscrimination statutes have their funding

124. See BorIS I. BIrTKer, THE CASE FOR BLACK REPARATIONS 9 (1973) (arguing that reparations for segregation are more appropriate than for slavery because with the passage of time, the white profit froin slavery "may well have been dissipated.")

125. 438 U.S. at 400 .

126. With respect to the Equal Opportunity Act, the section-by-section summary of the legislation notes that "a preference in contracting based on economic criteria ... is not forbidden by this Act." 141 Cong. Rec. S10,830 (July 27, 1995). But Senator Dole's proposed alternative to racial preferences includes no call for class-based preferences. See Bob Dole \& J.C. Watts Jr., $A$ New Civil Rights Agenda, WALl Sr. J., July 27, 1995, at A11. By contrast, see Newt Gingrich's supportive statements about class-based affirmative action. John F. Harris, President May Appoint Panel to Study Preference Programs, WASH. Post, Apr. 10, 1995, at A1, A9.

With respect to the California Civil Rights Initiative ("CCRI"), soine of its key backers say that they support class-based affirmative action as an alternative to race and gender preferences. Paul M. Barrett \& G. Pascal Zachary, Budding Backlash? Race, Sex Preferences Could Become Target In Voter Shift to Right, WALI ST. J., Jan. 11, 1995, at A1, A5 ("Mr. [Toin] Wood says he favors some alternative to affirmative action based solely on need and ignoring sex and race-at least for entrylevel jobs and college admissions."); see also John Boudreau, Effort to Outlaw Affirmative Action Promoted in Califormia, WASH. Post, Dec. 27, 1994, at A3 ("Assemblyman Bernie Richter, a Republican from Chico [Cal.], introduced a similar anti-affirmative action amendnient in the state Assembly in early December. His legislation would support preferences only for economically disadvantaged people applying for entry-level positions."). But the CCRI itself contains no positive provision for class-based preferences. Proponents of that alternative are apparently asked to support CCRI and take it on faith that class preferences will appear down the road.

127. Reinariks, supra note 4.

128. Id. 
cut back, and as Republicans attempt to limit the amount of damages awarded in racial discrimination cases. ${ }^{129}$

Furthermore, Dole's approach would generally prohibit all public racial preferences, even those rare ones that are in fact narrowly tailored responses to proven and egregious discrimination. ${ }^{130}$ Occasionally, a federal race-based program may be justified to remedy egregious discrimination of the kind outlined in Paradise. In such instances, the Dole bill leaves the federal government powerless to fashion an effective, narrowly tailored remedy on its own. The CCRI would leave California in the same position.

\section{III}

\section{The Class-Based Approach: A Progressive Alternative}

\section{A. The Case for Class-Based Affirmative Action}

If Adarand invalidates many current race-based programs, and if the major alternatives in the political debate over affirmative action are unsatisfactory, then there are strong moral, political, and legal reasons for those concerned about remedying the legacy of past discrimination to back a new plan for class-based affirmative action. Below, I lay out the case for such a policy, analyze how such a program might work in practice, and describe the continuing, but narrow role for race-based preferences within a class-based model.

\section{The Moral Case}

Class-based affirmative action does a better job of providing equal opportunity than either the current system of affirmative action or a policy of inaction. Class preferences will indirectly compensate for past discrimination, bring about a natural integration, and provide a bridge to a color-blind future.

The first and major advantage to the class preference proposal is that it clearly and unambiguously advances the goal that Clinton and Dole both purport to champion: equal opportunity. It is commonly acknowledged that if a child is born poor, she has less chance of getting ahead than a child born into the upper or upper-middle classes-even if the poor child is just as naturally talented and hard working as her more

129. Between the fiscal years 1981 and 1994, the number of federal employees enforcing civil rights laws declined by $19 \%$, according to a study of the U.S. Civil Rights Commission. Federal Commission Criticizes Slow Enforcement of Civil Rights, WASH. Post, June 24, 1995, at A5. The 1995 Republican-backed tort reform measure sought to cap damages in civil cases, including cases involving intentional racial discrimination. Nancy E. Roman, First Legal Reforms Clear House; "Loser Pays" Bill Ok'd 232-193, WASH. Times, March 8, 1995, at A1.

130. Rather than codifying Adarand, which subjects federal preferences to strict scrutiny, Dole's legislation prohibits all federal preferences on the basis of race, color, national origin, or sex. See supra note 113. 
advantaged peer. As Northwestern University sociologist Christopher Jencks has noted, "If we define 'equal opportunity' as a situation in which sons born into different families have the same chances of success, our data show that America comes nowhere near achieving it.... [T] he sons of the most advantaged fifth could expect to earn $150 \%$ to $186 \%$ of the national average, while the sons of the least advantaged fifth could expect to earn $56 \%$ to $67 \%$ of the national average." ${ }^{131}$

Because it is very difficult (both expensive and intrusive) to equalize starting places, class preferences seek to adjust for the latent potential of those who have faced obstacles and done fairly well nonetheless. In this sense, class preferences are actually meant to perfect the meritocracy rather than subvert it. Whereas a racial preference will unfairly benefit Bill Cosby's offspring over the son of a white sanitation worker, class preferences help those who need it. It is a policy that can be described overtly, accurately, and unashamedly. Replacing race preferences with class preferences redirects both the Republican and Democratic oars so that they all pull in the same direction-for greater equality of opportunity.

Soine argue that providing preferences based on class is not much different from our current race-based system. But this claim misses a very real distinction: under the race-based system, preferences can and often do go to the most advantaged people of color, who because of an advantaged background can beat out their less privileged counterparts. ${ }^{132}$ At Harvard, for example, seventy percent of African American students have professional or managerial parents. ${ }^{133}$ By contrast, under a class-based systein, the African Americans who benefit will represent a very different group. They will be those who have faced very real classbased obstacles. And, of course, some lower-income whites also will benefit in a way they could not under a race-based preference system.

Second, class-based preferences indirectly compensate for past discrimination in a way that former Senator Dole's approach does not. Dole is right to criticize racial preferences: it is almost always too speculative to say that because of past discrimination against a racial group, an individual member of that group, no matter how wealthy, deserves a preference. But most people do realize that the poor lack opportunity-and that because of past discrimination, many of those who are poor are black.

131. Christopher Jencks et al., Who Gets Ahead? The Determinants of Economic SUCCESS IN AMERICA 82-83 (1979).

132. Reporters often miss the distinction as well. A Reuters report written prior to the University of California Board of Regents' vote to replace race with class preferences said, "Critics of the move have said it would widen the gap between rich and poor." Governor Threatens Jesse Jackson With Arrest, WASH. POST, July 17, 1995, at A7.

133. Michael Lind, The Next American Nation 168 (1995). 
Martin Luther King, Jr. argued that class-based programs offer an appropriate remedy for past discrimination. King agreed with today's proponents of racial preference that compensation is due. He wrote, "[I]t is obvious that if a man is entered at the starting line in a race three hundred years after another man, the first would have to perform some impossible feat in order to catch up with his fellow runner." 134 But his proposed remedy was a Bill of Rights for the Disadvantaged. "It is a simple matter of justice," King wrote, "that America, in dealing creatively with the task of raising the Negro from backwardness, should also be rescuing a large stratum of the forgotten white poor."135

Thirty years later, President Clinton has trouble speaking directly about racial preferences because he realizes that they contradict King's basic moral message: that race is immutable, an accident of birth, and should not be the basis for handing out jobs, contracts, or college admission letters. It is true that part of the reason Clinton denies the reality of preferences is that they go against the interests of whites, who still make up seventy-five percent of the nation's population, and an even greater percentage of its voters. ${ }^{136}$ Civil rights statutes also went against the narrow interests of whites, taking away an unfair preferential system from which whites had benefited, but most white Americans now profess to believe in nondiscriminatory procedures because they believe them to be "right." A color-blind way of remedying past discrimination would accomplish the task without contradicting the basic moral thrust of the civil rights movement.

\section{The Political Case}

President Clinton argues that the issue of affirmative action should not be used to "divide our country at a time when, if we're really going to change things, we have to be united." bring our people together." ences that, by its very nature, divides people, often in a way that is politically disastrous for progressives. Class-based preferences, on the other hand, do not suffer from this handicap.

134. Martin Luther King, JR., Why We CaN'T Wait 147 (1963).

135. Id. at 152 .

136. Non-Hispanic whites constituted $73.6 \%$ of the population in 1995 . BUREAU of THE Census, U.S. Dep't of Commerce, Statistical Abstract of the United States 19 (1995). Furthermore, although the inclusion of women in affirmative action programs should in theory strengthen the political appeal of preferences, in fact most women opposc preferences, even for themselves. See, e.g., Richard Morin \& Sharon Warden, Americans Vent Anger at Affirmative Action, WASH. Post, Mar. 24, 1995, at A1, A4 (finding that $66 \%$ of women oppose gender preferences, compared to $75 \%$ of men).

137. Remarks, supra note 4.

138. Id. 
Martin Luther King, Jr. warned that racial preferences would divide working-class whites and blacks. ${ }^{139}$ Indeed, President Richard Nixon saw his promotion of the Philadelphia Plan for racial quotas in the city's construction industry as a strategic way to divide labor and civil rights groups. Presidential aide John Ehrlichman recalled in his memoir that "Nixon thought Secretary of Labor George Schultz had shown great style in constructing a political dilemma for the labor union leaders and civil rights groups. ... Before long, the AFL-CIO and the NAACP were locked in combat over one of the passionate issues of the day . . ."140 Clinton, however, completely misconstrues Nixon's role. In his National Archives address, Clinton said, "It is, in a way, ironic that this issue should be divisive today, because affirmative action began [sic] 25 years ago by a Republican president with bipartisan support." "141

After a quarter-century of experience with affirmative action and racial preference policies, the claim that they "bring people together" is hard to sustain. Preferences can bring greater integration, but they can also foster resentment and "group think." Conservative commentators were not entirely misguided in connecting the theory behind affirmative action with the theory that O.J. Simpson should be acquitted, given the history in this country of whites being set free for crimes they clearly committed. ${ }^{142}$ Many saw the Simpson verdict as affirmative action run amok--preference for a black defendant in response to years of discrimination against other black defendants.

By contrast, class-based preferences provide benefits in a way that is politically productive for those concerned about inequality. Like any preference program, class-based preferences divide people into categories-those born with unearned economic advantage are pitted to some degree against those born into unearned economic disadvantage. Thus, replacing race preferences with class preferences will decrease public consciousness of race and increase public consciousness of class. For progressives, this shift has always been a political imperative. When Jesse Jackson ran for president, he argued for a class-based, multiracial Rainbow Coalition. He said it is time to "leave the racial battle ground

139. David J. Garrow, Bearing the Cross: Martin Luther King, JR., and the Southern Christian Leadership Conference 312 (1986).

140. John EhrLichman, Witness To Power: The Nixon Years $228-29$ (1982).

141. Remarks, supra note 4.

142. See, e.g., George F. Will, Circus of the Century, Wash. Post, Oct. 4, 1995, at A13 (noting that "it is not surprising that the [Simpson] jurors had no pangs of conscience about regarding Simpson merely as a member of a group-and not seeing his victims at al1"). Once again, Clinton completely misread the issue. In his University of Texas speech following the Simpson verdict, Clinton said, "I want to mend affirmative action, but I do not think America is at a place today where we can end it. The evidence of the last several weeks shows that." Rift Between Blacks, Whites "Is Tearing at the Heart of America," (text of address on race relations delivered by President Clinton at the University of Texas) WASH. Post, Oct. 17, 1995, at A13. 
and come to the economic common ground."143 Although Jackson remains a strong supporter of race-based preferences, he and other progressives should understand that there is no better way to unite a progressive coalition for change than to remind its racially diverse members of their common economic interests.

\section{The Legal Case}

Third, class-based preferences provide a constitutional way to achieve greater racial and ethnic diversity, because they do not use a suspect category for decision making. Racial preferences are subject to strict scrutiny under the Fourteenth Amendment, but class preferences are not. And therein lies a great legal irony.

For many years, progressives pitched arguments in terms of race rather than class, because they knew that if they were successful in characterizing a law as racially discriminatory, the courts would apply strict scrutiny and strike the law down. Where a unanimous court would strike down the racial unfairness of school segregation in Brown $v$. Board of Education, ${ }^{144}$ the Court refused to strike down the class-based unfairness of inequitable public school funding in San Antonio Independent School District v. Rodriguez. ${ }^{145}$ Various efforts by lawyers on the left to get "class" designated as "suspect" have failed. ${ }^{146}$ As Professor John Ely notes, "[T] he once glittering crusade to extend special constitutional protection to the poor has turned into a rout."147

Today, ironically, progressives are faced with precisely the opposite dynamic. In the remedial phase, most of the racial laws being subjected to strict scrutiny are not those that hurt people of color, but rather are affirmative action remedies intended to help them. Because class is not a "suspect" category in Equal Protection jurisprudence, however, preferences for the poor are not subject to the strict scrutiny that government affirmative action programs face under Adarand and Croson. Indeed, class-based preferences are often described by members of the Supreme Court as a clearly constitutional alternative to racial preferences. ${ }^{148}$ Hence, class-based preferences enjoy a legal viability that racebased programs do not.

143. Raymond S. FrankLIN, Shadows of RACE aNd Class 20 (1991).

144. 347 U.S. 483 (1954).

145. 411 U.S. 1 (1973).

146. See, e.g., Harris v. McRae, 448 U.S. 297, 321-22 (1980) (finding, in the context of denial of federal funding of abortions for indigent women, that poverty is not a suspect classification); James $v$. Valtierra, 402 U.S. 137 (1971) (holding that the Califomia requirement of mandatory referendums for construction of low-cost public housing projects did not violate the Equal Protection Clause).

147. JoHN H. ELY, DEMOCRACY AND Distrust: A THEORY OF Judicial REview 148 (1980).

148. See, e.g., City of Richmond v. J.A. Croson Co., 488 U.S. 469, 509-10 (1989) (O'Connor, J.); id. at 526-28 (Scalia, J., concurring); DeFunis v. Odegaard, 416 U.S. 312, 331 (1974) (Douglas, J., dissenting). To a lesser degree, we have already seen this phenomenon play out with respect to 


\section{B. Class-Based Affirmative Action in Practice}

Considering the moral, political, and legal viability of class-based preferences, it becomes imperative to construct a workable class-based affirmative action program. Several questions arise. How might classbased affirmative action work in practice? How is "class" to be defined? Should only the poor benefit or lower-middle income Americans as well? Should there be a sliding scale of benefits? In what contexts should class preferences apply? University admissions only? Employment as well? Public contracting? Should class preferences apply to people of all ages? To promotions as well as hiring? Would preferences be voluntary or mandatory? How substantial should the preferences be? Would class preferences entirely displace racial and gender preferences?

Some blanch at the weight of these questions. "The difficulties of measuring disadvantage seem imsurmountable," says the Citizens' Commission on Civil Rights. ${ }^{149}$ "There isn't one simple or generally accepted way to identify or determine 'need,"' says the National Women's Law Center..$^{150}$ Columnist Michael Kinsley asks, "Does Clarence Thomas the sharecropper's kid get more or fewer preference points than the unemployed miner's son from Appalachia?"151 The American Lawyer's Stuart Taylor likewise wonders, "How many points for attending an all-black inner-city school v. a second-rate white suburban school? How many for a family income of under $\$ 10,000$ ? Under $\$ 20,000$ ? For a mediocre small-town high school? A deserting father? An alcoholic mother?"152

Most proponents of class-based affirmative action have failed to explain their ideas with any specificity. ${ }^{153}$ The questions of implementation are indeed serious and difficnlt, but they are not impossible to answer. Within universities, for example, admissions committees deal every day with precisely the types of apples-and-oranges questions that

gender-based affirmative action: because gender is not fully suspect, gender preferences are easier to sustain. See Memorandum to General Counsels, supra note 3, at 8 (citing six circuit court opinions, five of which applied the more lenient intermediate scrutiny standard to gender preferences).

149. Citizens' Commission on Civil Rights, AfFirmative Action to Open the Doors OF JOB OPPORTUNITY 160 (1984).

150. National Women's Law Center, Need-Based Programs Are No Substitute for Affirmative Action, Apr. 1995, at 2. The NWLC says it is a group dedicated to promoting the legal rights of women "with special attention given to the concerns of low-income women." Id. at 3.

151. Michael Kinsley, Class, Not Race, Wash. Post, Aug. 1, 1991, at A15.

152. Stuart Taylor Jr., A Case for Class-Based Affirmative Action, CoNN. L. TriB., Sept. 30, 1991, at 23.

153. "This idea of basing affirmative action on social class rather than race has gotten little of the serious exploration it deserves .... Conservatives like Thomas and Scalia have not offered the kind of detailed proposal that would evidence real enthusiasm for class-based affirmative action." Taylor, supra note 152. See also Steven A. Holmes, Mulling the Idea of Affirmative Action for Poor Whites, N.Y. Trmes, Aug. 18, 1991, §4, at 3. 
Kinsley and Taylor pose. Should a law school admit an applicant with a 3.2 GPA from Yale or a 3.3 from Georgetown? How do you compare those two if one applicant worked for the Peace Corps but the other had a slightly higher LSAT score? In reality, many universities already give preferences to disadvantaged students in addition to racial minorities, and class preferences have been used in certain employment and public contracting contexts as well. ${ }^{154}$

Three principles should guide the establishment of a classpreference system. First, the system's primary goal must be to provide genuine equality of opportunity, where natural talents may flourish to their full potential. In order to do this, we should create an obstacles test, which says that if a given individual did quite well, despite various impediments, then she is very talented and/or very hardworking; she deserves an edge because she has great long-run potential. The goal is not to absolve people from responsibility for their own actions. Rather than excusing underachievement, we are saying that if an individual has faced serious obstacles and been relatively successful anyway, she has something special worth developing.

Second, we want a system that can in fact be administered. The Manhattan Institute's Abigail Thernstrom rightly ridicules the notion of providing preferences to someone with "a handicapped mother, an alcoholic father, a depressed sister and a drug-dealing brother."15s We want the system to process information that is verifiable. Although we may be interested in knowing if an applicant did quite well despite growing up in a household with no books and without enough "quality time" with his parents, it is much easier to verify the parents' income, education, and occupation. A system without objective criteria will be fraught with abuse. Stiff penalties for fraud will stick only when the measures of disadvantage are objective.

Third, we want a program that can actually be adopted in our nation's republican form of government. A theoretically sound program, even one that is administrable, is merely idle chatter unless it is politically palatable to elected officials. Legislation is essential since, unlike racial remedies, which are sometimes imposed by the judiciary, there is virtually no chance that the Supreme Court will impose class-based affirmative action as a constitutional mandate.

The following discussion outlines one possible approach, which seeks to adhere to the three principles. People may differ on the particulars. The critical point, however, is not that the plan is perfect, but that there are objective and quantifiable ways to measure disadvantage and make this system work.

154. See supra Section III.B.1.

155. Abigail Thernstrom, A Class Backwards Idea, WASH. Post, June 11, 1995, at C1, C2. 


\section{Where Should Class-Based Preferences Apply?}

As a threshold matter, in what contexts would class-based affirmative action apply? To provide genuine equal opportunity, rather than equal results, class-based affirmative action should apply at "meritocratic crisis points" relatively early in life. ${ }^{156}$ When economically disadvantaged teens apply to college or for an entry-level job, their disadvantage, though no "fault" of their own, may hide their true potential. With this basic guideline in mind, we consider the applicability of class-based affirmative action to education, employment, and public contracting.

In education, class preferences make sense in the university admissions process, both because applicants are still generally young, and because universities already have access to a wealth of information about an applicant's background. In many ways, colleges and graduate schools are the modern gatekeepers, deciding who gets ahead and who does not, so that it is natural that much discussion of class-based affirmative action has focused on university admissions.

Since 1991, the University of California at Berkeley has given special consideration to applicants "from socioeconomically disadvantaged backgrounds ... regardless of race or ethnicity."157 In recent years, between sixteen and eighteen percent of the freshman class received a leg up in admissions, based on a disadvantage index measuring parental income, education, and occupation. ${ }^{158}$ Since the 1970's, Temple University Law School has given preference to "applicants who have overcome exceptional and continuous economic deprivation."159 Nearly fifty percent of the class is admitted under the Special Admissions and Curriculum Experiments (S.p.A.C.E.) program, which gives special consideration primarily to minority and disadvantaged applicants. ${ }^{160}$ At Hastings College of Law in California, twenty percent of the class is set

156. The phrase "meritocratic crisis points" is from Kinsley, supra note 151.

157. Committee on Admissions and EnRollment, University of CALIForNia, Freshman Admissions At Berkeley: A Policy for the 1990s AND Beyond 43 (1989) (Karabel report). Adopted in 1989, the program was first implemented in 1991. Telephone Interview with Robert Laird (July 18, 1995) [hereinafter Laird Interview]; see also DaNA Y. TAKAGI, The RETREAT FROM Race: Astan-American Admissions and Racial Politics 154 (1992).

158. Laird Interview, supra note I57.

159. Temple University Law School Admissions Brochure, 1994-95, at 45 [hereinafter TEMPLE ADMISSIONS BROCHURE].

160. Telephone Interview with Robert J. Reinstein, Dean, Temple University Law School (Dec. 14, 1994) [hereinafter Reinstein Interview]. S.p.A.C.E. gives special consideration to six groups. TEMPLE ADMISSIONS BROCHURE, supra note 159, at 45. Dean Reinstein said that the following categories-enumerated minority status and history of cconomic deprivation-are the two dominant criteria. He further explained that while race is a separate plus in the admissions process, all other things being equal, a disadvantaged white candidate normally has a better chance of admissions than an advantaged minority applieant. In fact, a majority of those admitted under S.p.A.C.E. are white. Reinstein Interview, supra. 
aside for disadvantaged students through the Legal Equal Opportunity Program (LEOP) ${ }^{161}$ And in New York, the Higher Educational Opportunity Program (HEOP) provides financial incentives to colleges that admit low-scoring disadvantaged students of all races. ${ }^{162}$ Even the UC Davis medical program at issue in Bakke was limited to "disadvantaged" minorities, a system which Davis apparently did not find impossible to administer. ${ }^{163}$

If required of universities, such preference systems would need to be accompanied by guarantees of financial aid and some forn of remedial education-perhaps a mandatory summer program prior to the beginning of the first year. Just as important, class-based affirmative action would mean modifying or eliminating existing preferences that tend to hurt those from lower socio-economic classes. Such preferences, in current practice, include alumni preferences and preferences for applicants from preparatory schools. ${ }^{164}$ If a university insisted on providing alumni preferences, it would forego federal funding. Application of the class preference principle to elementary and secondary schooling should also be explored. ${ }^{165}$

161. Telephone Interview with Algera Tucker, Assistant Director, LEOP Program, Hastings College of Law (Nov. 4, 1994). Race is considered a plus in LEOP admissions, but advantaged people of color do not qualify for LEOP. Id.

162. 1993-94 HEOP ANN. REP. SUMmARY. For example, at Bard College, according to HEOP official Gabriel N. Mendes, students not normally admissible are given a break if they are educationally disadvantaged, regardless of race. Letter from Gabriel N. Mendes, HEOP Office, Bard College, to the editor of The New Republic (April 12, 1995) (on file with author).

163. See Bakke, 438 U.S. at 274-75. In addition, Harvard University has no trouble sorting Asian applicants into "blue collar" and non-"blue collar" applicants. U.S. Dep't of Education, Statement of Findings, Compliance Review No. 01-88-6009, at 16 (Oct. 4, 1990) (on file with author).

164. Although less well publicized than alumni preferences, there is evidence that some colleges currently give prep school applicants preferences in admissions. At Harvard, notes David Karen, "Going to prep school almost doubles the chances that a white applicant will be admitted." TAKAGI, supra note 157, at 31 (quoting David Karen, Who Gets into Harvard? Selection and Exclusion at an Elite College (1985) (unpublished Ph.D. dissertation, Dep't of Sociology, Harvard University)).

165. While class preferences are often discussed in the context of university admissions, there is a strong case for applying preferences to admission to selective public and private primary and secondary schools, and to tracking within primary and secondary schools. Under current tracking procedures, low socioeconomic status (SES) children are generally tracked low, high SES children high. Many years ago, Ray Rist argued that tracking provides a central explanation for the reproduction of class status over generations. Ray C. Rist, Student Social Class and Teacher Expectations: The Self-Fulfilling Prophecy in Ghetto Education, 40 HARv. EDUc. REv. 411 (1970). Rist spoke of the "self-fulfilling prophesy" of low SES kids, placed in low tracks and expected to do little, doing about as much as expected, while high SES-high track kids, being continually challenged, perform to their natural limits. Id. For a more recent assessment of the literature, which confirms much of Rist's observations, see Patrick Shannon, Reading Instruction and Social Class, 62 LANGUAGE ARTS 604 (1985).

Whatever one thinks of tracking pedagogically (and there are strong arguments for it), it is likely to continue, for it is popular among teachers. Moreover, tracking by social class is likely to continue not because teachers are malevolent, but because social class is highly correlated with educational preparedness, even in kindergarten. What I am arguing for is a marginal preference. When a lower-class student does well, not as well as her typical middle-class peers, but better than we would 
In the employment arena, class-based preferences could be implemented by public employers and federal contractors. In 1994, for example, the Clinton Administration issued regulations that require a hiring preference for low-income workers in the federal construction of new public housing. ${ }^{166}$ Again, such a preference makes particular sense for those just graduating from high school and not pursuing college,

expect given her obstacles, then we should bump her up, in the hope that the self-fulfilling prophesy is a brighter one.

The phrase "better than we would expect" underlines why it is crucial that such programs be class- rather than race-based. While it is reasonable to have low expectations for poor people because of the obstacles they face, it can be racist to have low expectations for upper-middle class blacks. According to Stephen Carter, Harvard Law School initially rejected him, then phoned him to offer a slot, indicating that the school had "assumed from your record that you were white." Stephen L Carter, Reflections of an Affirmative Action Baby 15 (1991). Carter noted, "Stephen Carter, the white male, was not good enough for the Harvard Law School; Stephen Carter, the black male, not only was good enough, but rated agonized phone calls urging him to attend. And Stephen Carter, color unknown, must have been white: How else could he have achieved what he did in college?" Id. at 16.

The tracking preference cannot be a large one, for a substantial preference would defeat the whole idea of tracking, but on the margins, a small preference could make a genuine difference in the lives of thousands of disadvantaged kids. The problem is that once a child is placed in a lower track, her aspirations often decline, and even students who are misplaced in a low track often end up remaining there. See, e.g., Committee on Ability Testing, National Research Council, Ability Testing: Uses, Consequences, and Controversies pt. I, at 174-75 (Alexandra K. Wigdor \& Wendell R. Garner eds., 1982) (arguing for reversibility of tracking assiguments).

In addition, selective public and private schools should provide class preferences so that highly talented and motivated students from poor backgrounds will develop their skills to the point where they can apply to, be accepted at, and succeed in rigorous university programs. In May and September of 1994, the Wall Street Journal ran two heartbreaking stories about Cedric Jennings, a hardworking, mtelligent black student at decrepit and dangerous Frank W. Ballou Senior High School in Washington, D.C. Jennings hid in the chemistry lab and avoided gangs, but also avoided student assemblies where bright students were jeered for winning academic prizes. He dreamed of going to M.I.T. and attended a summer session for minority students, where he was out-competed by affluent black students who ridiculed his Washington street slang. He scored 910 on his S.A.T, and was told by a white MIT professor, "I don't think you're M.I.T. material." Jennings blamed the professor, accusing him of racism. But the professor is, of course, right: it does no one any good to admit an individual to a university at which he or she is likely to fail. The answer is reaching students like Jennings earlier. In his case, he was offered a scholarship at a private school and inexplicably turned it down, but there are many other Cedric Jennings who do not have that opportunity. Ron Suskind, In Rough City School, Top Students Struggle to Learn-and Escape, WALl ST. J., May 26, 1994, at A1; Ron Suskind, Poor, Black and Smart, An Inner-City Teen Tries to Survive M.I.T., Wall ST. J., Sept. 22, 1994, at A1.

166. I2 U.S.C. $\$ 1701 u$ (1994). Section 1701 u(b) provides, "[E]mployment and other economic opportunities generated by federal financial assistance for housing and community development programs shall, to the greatest extent feasible, be directed toward low- and very low-income persons, particularly those who are recipients of general assistance for housing." Section $1701 \mathrm{u}(\mathrm{d})(\mathrm{I})(\mathrm{A})$ provides: "The Secretary shall require... contractors and subcontractors [to] make their best efforts ... to award contracts ... to business concerns that provide economic opportunities for lowand very-low income persons." Paul Sonn of the NAACP Legal Defense \& Education Fnnd brought this program to my attention. 
because at that age, their class-based handicaps hide their true potential and are not at all of their own making. ${ }^{167}$

Indeed, it is crucial that class preferences not be limited to university admissions alone, for to do so would bypass countless students who go straight from high school to the job market. In 1991, 34.1\% of all whites between eighteen and twenty-four were enrolled in college; the comparable figure was just $23.6 \%$ for African Americans and $18 \%$ for Hispanics. ${ }^{168}$ Among young adults from the bottom quartile of family income, just $30 \%$ go to college. ${ }^{169}$ Giving preferences in college admissions is crucial, because college is more than ever the key to upward mobility, but preferences must apply to entry-level employment as well if we are to assist the majority of poor and working-class individuals in this country. For example, India has for decades been running a hybrid caste-class form of affirmative action for employment, which includes consideration of caste, income, occupation, education, and region. ${ }^{170}$

Preferences make less sense im promotions and in lateral hiring of older employees, particularly for skilled positions. ${ }^{171}$ Entry-level employees often require training and are in that sense analogous to university students; more senior positions, by contrast, may require instantaneous high-skilled performance. But the fact that class preferences would not apply to promotions later in life is no reason for alarm. The argument for preferences is strongest when we are giving individuals a fair chance of proving themselves. Just as universities that provide admissions preferences do not provide racial preferences in grading, so in employment, the case for preferences is much stronger in hiring than

167. Preferences are especially appropriate for the many entry-level positions which require applicants to take tests as a screening device. The Educational Testing Service, which administers the SAT, also provides tests for 50 different occupations, including firefighting and police work. allan Nairn \& associates, The Reign of ETS: The Corporation that Makes Up Minds 32 (1980). One study found that among employers with over 1000 employees, more than $50 \%$ used testing in hiring. COMMITTEE ON ABILITY TEsTING, supra note 165, at 110. The federal government is a heavy user of testing, both in civilian and military positions, and among state and local governments; written tests are employed for between $65 \%$ and $88 \%$ of skilled positions. Id. at 135 ; see also Dinesh D'Souza, The END of Racism: Principles for a Multiracial Society 309 (1995).

168. Economic Factors Put Minority Gains at Risk, Higher Educ. \& NAT'L AfF. (Am. Council on Educ., Washington, D.C.), Jan. 25, 1993, at 1, 3; see also Fox Butterfield, Colleges Luring Black Students With Incentives, N.Y. Times, Feb. 28, 1993, § 1, at 1.

169. Tim W. Ferguson, Income Disparity and the Democrats, Wall ST. J., Aug. 30, 1994, at A11.

170. See Samuel M. Witten, Comment, "Compensatory Discrimination" in India: Affirmative Action as a Means of Combatting Class Inequality, 21 CoLUM. J. TRANSNAT'L L. 353 (1983).

171. Indeed, Ross Perot does not today deserve a preference simply because he was born poor. Jeffrey Rosen notes, correctly, that it would be ridiculous for a sharecropper's son, 10 years into his job, to receive a preference in promotion to office manager over a peer with a more advantaged childhood. Jeffrey Rosen, Affirmative Action: A Solution, New Republic, May 8, 1995, at 20, 22. 
in promotion. ${ }^{172}$ Furthermore, the impact of giving an individual a chance at a first job should not be underestimated. Sociologists Otis and Beverly Duncan, and David Featherman report that " $[t]$ he occupational level at which a man begins his career is substantially predictive of the level at which he will be found at any age between 25 and 64."173 The guiding principle, then, must be a fair shot at performing, not a guaranteed equal result. Ongoing racial and gender discrimination in proinotion-the so-called "glass ceiling"-can still be combated by the Civil Rights Act of 1991, which requires the employer to justify race or gender imbalances in promotion by the legal standard of "business necessity."174

In public contracting, preferences could also be appropriately tailored. At first glance, granting preferences to low- and lower-middle incoine people appears difficult to apply, since most owners of coinpanies in a position to bid are not low or lower-middle income. ${ }^{175}$ But race-neutral class-based preferences can nevertheless be franed to give a leg up in contracting to those companies headed by individuals who are disadvantaged relative to the competition, and/or companies that employ workers who are disadvantaged and are located in disadvantaged census tracts.

In Croson, for example, Justice Scalia noted that states could "adopt a preference for small businesses, or even for new businesseswhich would make it easier for those previously excluded by discrimination to enter the field. Such programs may well have a racially disproportionate inpact, but they are not based on race."176 Justice O'Connor spoke even more broadly about taking race-neutral steps to address the barriers faced by many small and minority-owned businesses. "Simplification of bidding procedures, relaxation of bonding requirements, and training and financial aid for disadvantaged entrepreneurs of all races," she wrote, "would open the public contracting inarket to all those who have suffered the effects of past societal discrimination or neglect."177

Many federal programs already give preferences to small businesses, and even currently race-based programs (such as the section 8(a) set-aside program) use disadvantaged status as a criterion. ${ }^{178}$ To the extent that the racial component of preferences for companies owned by "socially and economically disadvantaged" individuals drops away af-

172. See CARTER, supra note 165 , at 89 .

173. Otis D. Duncan et AL., Socioeconomic Background and ACHIEvement 252 (1972).

174. Civil Rights Act of 1991, 42 U.S.C. § 1981 (1994).

175. See, e.g., Nathan Glazer, Race, Not Class, WALl St. J., Apr. 5, 1995, at A12.

176. Croson, 488 U.S. at 526 (Scalia, J., concurring).

177. Id. at 509-10 (O'Connor, J.).

178. I5 U.S.C. $\$ \S 637(a)(1)$, (4) (1994). 
ter Adarand, programs to help small struggling businesses will remain. For example, before the Adarand decision, the FCC had proposed providing a $25 \%$ discount for wireless communication licenses to women and minority-headed companies with $\$ 40$ million or less in revenue. After Adarand, the FCC proposed that all small businesses with revenues below $\$ 40$ million receive a $25 \%$ bidding credit. ${ }^{179}$ Likewise, shortly after the District of Columbia's racial set- aside program was struck down as unconstitutional, the District established a $50 \%$ set-aside for local small businesses owned by disadvantaged people of all races. ${ }^{180}$

Alternatively, programs can look at businesses' location or employees. In 1980, Mayor Edward Koch instituted an affirmative action program in New York City based on economic deprivation rather than race or ethnicity. The program established a $10 \%$ subcontracting setaside to small firms (those with annual gross receipts of less than $\$ 500,000$, or $\$ 1.5$ million for heavy construction) located in New York City that did at least $25 \%$ of their business in depressed areas or employed (as $25 \%$ of their workforce) economically disadvantaged workers. Depressed areas were defined as economically deprived by census tracts, and economically disadvantaged workers were those legally defined as hard-core unemployed (out of work for forty weeks). Bonding requirements were waived for certified subcontractors, and the city offered technical assistance and working capital loan guarantees as well. The program disproportionately helped women and people of color. Although Koch's successor, David Dinkins, abolished the program in favor of a more traditional set-aside scheme, the Koch plan has served as a model for cities that have seen their own racial set-aside programs struck down in the courts under Croson. ${ }^{181}$

In a similar vein, Philadelphia Mayor Edward G. Rendell has proposed that $15 \%$ of federal contracts be set aside in a race-neutral manner to distressed urban areas. ${ }^{182}$ In 1995, President Clinton proposed supplementing race and gender construction set-asides with a set-aside for employers who locate in "distressed areas," or employ a large per-

179. Mike Mills, FCC May Drop Race, Sex Preferences, Wash. Post, June 22, 1995, at AI, A20; see also FCC Chooses Aug. 29 for the Next Auction of Its PCS Licenses, WALL ST. J., June 26, 1995, at C15; Pearl, supra note 112. The FCC reserved the right to reinsert race and gender preferences in subsequent auctions. Id.

180. Setback for Set-Asides, WASH. PosT, Dec. 31, 1992, at A26 (editorial). Interestingly, the Post endorsed the program as "fairer" than the previous race-based program. Id. Some have said the District's program is a shell for a race-based preference scheme. See, e.g., Rosen, supra note 171 , at 25 (calling the newly revamped program a cover for the old race-based system). But if the allegation is true, then the new program, too, may be litigated and struck down in the courts.

181. Edward 1. Koch, Equal Opportunity-Without Minority Set-Asides, N.Y. Times, Feb. 20, 1989, at A19. See also Edward I. Koch, CITIZEN Koch: AN AutobiographY 164-65 (1992).

182. Thomas B. Edsall, City Tax Credits, Set-Asides Urged, WAsh. Post, Apr. 16, 1994, at A2. 
centage of workers from those areas. ${ }^{183}$ Similarly, Republican Senator Christopher Bond has called for set-asides for Historically Underutilized Business Zones (HUBZones) to funnel contracts to businesses in communities with low incomes and high unemployment. ${ }^{184}$ The potential models are numerous.

\section{Defining Socio-economic "Class"}

How should class be defined? The classic Marxist definition divides those who own the means of production from those who do not, ${ }^{185}$ but that definition is obviously unhelpful since only one percent of Ainerican households receive more than half their income from capital. ${ }^{186}$ In an early study of social mobility, Harvard's Seymour Martin Lipset defined class in terms of manual versus nonmanual occupations, and others have looked at blue-collar versus white-color occupations, ${ }^{187}$ but these definitions are becoming obsolete. The child of a middleincome steel worker may be more advantaged than the child of a singleparent bank teller. If our concern is with what Max Weber called one's

183. Remarks, supra note 4; see also Michael K. Frisby, Clinton Sees Need for Affirmative-Action Plans, But May Open Set-Aside Programs to Whites, Wall Sr. J., July 14, 1995, at A14. At the time, the Labor Department already was earmarking contracts for 1528 counties defined as labor surplus areas. Michael K. Frisby, Labor-Surplus Preferences May Be Pared, WALL ST. J., June 2, 1995, at Al2 (noting that the Clinton Administration may alter current set-aside programs, but is unlikely to abolish them entirely). In addition, the Empowerment Zone and Enterprise Communities Act of 1993 designated nine geographical Empowerment Zones and 94 Enterprise Communities for special breaks. Revitalizing America's Rural and Urban Communities: Hearings Before the Committee on Small Business of the United States Senate, 104th Cong., 1st Sess. (1995) [hereinafter Revitalizing Hearings] (statement of Senator Josepli I. Lieberman).

As currently structured, these programs and proposals do not limit beneficiaries to young, entrylevel employees, thougl in practice many of the beneficiaries may be young and almost all will fill entry-level rather than high-skilled or supervisory positions. This kind of class-based affirmative action program benefiting the poor of all ages is justified on two bases. First, even conservatives will concede that not all middle-aged poor people are entirely to blame for their economic position. Second, whether or not they are "to blame," there is a social good in providing the poor with special opportunities that will empower them. Companies that take on the burden of training and employing the hard-core unemployed, or locating in a poor neighborliood, are performing a public service for which the government may properly reward them.

184. Revitalizing Hearings, supra note 183 (opening statement of Sen. Christopher S. Bond, Chairman, Sen. Committee on Small Business); see also Paul M. Barrett \& Michael K. Frisby, "Place, Not Race" Could Be Next Catch Phrase In Government's Affirmative-Action Programs, WaLl ST. J., Oct. 18, 1995, at A22. HUBZones are similar to Enterprise Zones, but less costly. To the extent HUBZone set-asides replace existing racial set-asides, there is no additional cost to the federal government. By contrast, Enterprise Zones, which grant tax breaks to businesses locating in distressed areas, will produce revenue losses.

185. See, e.g., ERIK O. Wright, Class Structure and Income Determination 8 (1979).

186. Clay Chandler, It's Getting Awfully Crowded in the Middle, WASH. PosT, Dec. 18, 1994, at H1, H7 (citing Lawrence Mishel of the Economic Policy Institute for the proposition that only one percent of American louseholds receive more than half their income from capital).

187. Seymour Martin Lipset \& Reinhard Bendix, Social Mobility in Industrial SOCIETY 17 (1959). 
"life chances," 188 we want to identify criteria that will help us find those people who have extraordinary natural talent and a strong drive, but whose full potential is obscured by traditional ineritocratic criteria.

There are three basic ways to proceed: with a simple, moderate, or sophisticated definition. The simple method asks college or entry-level employment applicants for information about their families' income and measures disadvantage by that factor alone, on the theory that income is a good proxy for a whole host of economic disadvantages (such as bad schools, or a difficult learning environinent). The second, moderately sophisticated method would look at what inany sociologists consider the three biggest determinants of life chances: parental income, education, and occupation. The third, most sophisticated calculus of disadvantage would count these three factors plus such factors as net worth, quality of secondary education, neighborhood influences, and family structure.

Before considering which method makes most sense in which contexts, we must explore why each factor or potential factor is important and how one could objectively measure the factors in a verifiable manner.

\section{a. The Simple Definition}

The simple definition of class, which looks at family income, can be readily obtained by looking at tax returns. Bard College, for example, makes eligibility for its class-based program contingent upon a notarized copy of Internal Revenue Service Form 1040, or letters from a social service agency detailing an applicant's family incoine. ${ }^{189}$ Income figures can be adjusted to factor in family size using a formula readily available from existing anti-poverty programs. ${ }^{190}$ In addition, where a national pool of applicants is considered, income adjustments could be made to reflect large regional differences in cost of living. ${ }^{191}$ An existing federal formula, the Federal Employees Pay Comparability Act, al-

188. Max Weber, Class, Status, Party, in From MAX Weber: Essays in Sociology 181 (H.H. Gerth \& C. Wright Mills trans. \& eds., 1946).

189. Bard College Higher Education Opportunity Program Application Form.

190. Simply dividing family income by the number of family members (to come up with a per capita income figure) seems to overstate the impact of family size, since some living expenses (like heating a home) can be efficiently shared. On the other hand, ignoring family size altogether would also be unfair and, I argue, would negatively affect people of color. See KAHLENBERG, supra note 104, at ch. 6. In determining the poverty line, officials have applied a one-to-two ratio, so that the needs of a single individual are one-half that of a family of four. STEPHEN J. Rose, Social Stratification In the United States 9 (1992).

191. Kevin Phillips notes that to match the living standard $\$ 100,000$ bought in Minneapolis in 1990 , an individual would need an income of $\$ 112,700$ in New York City, $\$ 111,600$ in San Francisco, $\$ 110,000$ in Los Angeles, $\$ 106,200$ in Boston, $\$ 93,300$ in Miami, and $\$ 90,000$ in New Orleans. Kevin Phillips, Boiling Point: Republicans, Democrats, and the Decline of MiddleClass Prosperity 29 (1993). 
ready equalizes for such differences. ${ }^{192}$ Those who for privacy reasons object to disclosing family income would not be forced to do so, but would forgo the chance of receiving a class preference. ${ }^{193}$

\section{b. The Moderately Sophisticated Definition}

A second, moderately complex defmition of class would incorporate what sociologists consider the three main determinants of socioeconomic status, and what educators consider the key factors in a child's academic achievement: parents' income, education, and occupation. ${ }^{194}$ The University of California at Berkeley is one notable institution that currently employs this moderately sophisticated definition. ${ }^{195}$

\section{i. Education}

Parents' education is highly correlated with a child's academic achievernent and life chances. In fact, some studies suggest that a parent's education level is a better predictor of a child's educational attainment than parental income. ${ }^{196}$ For example, a private school teacher with a masters degree may make less than a unionized sanitation worker, but provide her child with greater educational advantages. At Berkeley, $68 \%$ of fathers of the 1987 freshman class had completed college, compared with $27 \%$ of fathers of similar age statewide. While between $47 \%$ and 56\% of Berkeley freshmen between 1977 and 1987 had mothers who attended college, the comparable statewide figure was only $14 \% .{ }^{197}$

192. Using data provided by the Bureau of Labor Statistics, the government pays its employees a supplemental "locality pay" in a number of areas in the nation, including Washington-Baltimore, Miami, San Diego, and Houston. See Stephen Barr, U.S. Workers Here to Get 3.21\% Raise, WaSH. PosT, Nov. 8, 1994, at Al.

193. In the college admissions context, more than half the student population already discloses family income as required on financial aid forms. See More than Half of All Students Need Financial Help After High School, WASH. PosT, Oct. 26, 1994, at A16. At elite schools, such as Harvard, the figure of those eligible for financial aid can approacl $70 \%$. See, e.g., Tuition Rises 5.4\%, HARV. MAG., May-June 1994, at 66.

194. See Susan E. Mayer \& Christopher Jencks, Growing Up In Poor Neighborhoods: How Much Does It Matter?, 243 SCIENCE 1441 (1989) (indicating in a review of numerous studies that tliree factors are the "standard" indicators of SES); see also Jonathan Crane, Effects of Neighborhoods on Dropping Out of School and Teenage Childbearing, in THE URBAN UNDERCLASS 299, 303-04 (Christopher Jencks \& Paul E. Peterson eds., 1991); Derek Bok, Admitting Success, New REPUBlic, Feb. 4, 1985, at 14 (noting that "[a]cademic achievement and persistence depend in some significant part on the parents' education, income, and occupation").

195. Laird Interview, supra note 157.

196. See, e.g., S. M. Miller \& Pamela Roby, Poverty: Changing Social Stratification, in ON Understanding Poverty: Perspectives from the Social SCIEnces 64, 71-72 (Daniel P. Moynilan ed., 1969). Likewise, the University of California found that father's and mother's education correlate more highly with student SAT scores and GPAs than does parental income. Office of the President, University of California, Occasional Paper No. 5, The Use of Soclo-Economic Status in Place of Ethnicity in Undergraduate Admissions: A Report ON THE RESULTS OF AN EXPLORATORY COMPUTER SIMULATION 15 (1995).

197. COMMTTTEE ON ADMISSIONS AND ENROLLMENT, supra note 157, at 43-45. 
Though there are ways to evaluate grossly the relative quality of university educations at various institutions, the inost straightforward way to measure parents' education is simply by number of years of schooling. ${ }^{198}$ Berkeley, for example, divides students between those whose parents received a four-year college degree and those whose parents did not. ${ }^{199}$

\section{ii. Occupation}

Parental occupation is another inportant determinant of a child's success. In fact, a father's occupational status has traditionally been a better predictor of his son's occupational status than the father's wealth. ${ }^{200}$ Occupation is a good predictor partly because it is closely tied to both education and income. ${ }^{201}$ Some say that occupation has an independent impact on a child's life chances above and beyond education and income. ${ }^{202}$ Whether or not this is true, counting for occupation is an additional check agamst fraud in the reporting of income and education.

For many years, occupation was designated by the father, but today it would be assigned to the "higher ranking" of the parents (or the average of the two). By considering occupation, we reflect the fact that eveu within the same family income group, a child growing up in a family where the father is a $\$ 60,000$-a-year attorney and the mother is home with the children is more advantaged than the child in a family where the father is a $\$ 40,000$-a-year steelworker and the mother is a $\$ 20,000$-a-year secretary.

On the surface, an occupation factor seems to open up an administrative hornet's nest. Some may even argue that it is impossible to say which parental jobs give children an advantage and which do not. But there are widely agreed-upon distinctions in the job market: salaried employee versus wage earner, mental versus physical labor, autonomous

198. Clearly, all American graduate schools already have ways of evaluating the quality of undergraduate institutions. Two semi-objective, broad ways to evaluate colleges are by selectivity, and by mean board scores. This is helpful only for very broad categories (e.g., most selective, highly selective, selective, and mean SAT above 1100 and below). Note also that applicants already provide information to colleges on their parents' education.

199. Laird Interview, supra note 157.

200. Stephan Thernstrom, The Other Bostonians: Poverty and Progress in the AMERICAN METROPOLIS 1880-1970, at 102 (1973).

201. Indeed, the Duncan Index, described below, ranks occupation based on education required and income received. See infra note 205 and accompanying text.

202. Melvin Kohn of the National Institute of Mental Health has argued that parental occupation serves as a fairly good proxy for the transmission of certain values that play "an important role in the perpetuation of the existing class order." DENN1s GILBERT \& JOSEPH A. KAHL, THE AMERICAN Class Structure: A New Synthesis 114 (4th ed. 1993) (paraphrasiug Kohn). Kohn found that lower-occupational-status parents tend to emphasize obedience, whereas higher status parents emphasize self-direction. Id. at 116-18. 
and self-directing managers and professionals versus those who receive commands and punch a time clock. ${ }^{203}$ Moreover, it is clear that some jobs have more or less power, more or less compensation, and more or less autonomy than others. They have greater or lesser societal importance (function) and require greater or lesser talent or training (scarcity). ${ }^{204}$

In fact, attempts to rank occupations objectively have been remarkably consistent over time. Because adult children rarely remember their parents' mcome, the mobility studies of sociologists normally focus on the parents' occupation. Over the years, sociologists have, by necessity, developed rather elaborate and accurate occupational rankings. ${ }^{205}$

203. See Barbara Ehrenreich, Fear of Falling: The InNer Life of the Middle Class $12-13(1990)$.

204. Kingsley Davis \& Wilbert E. Moore, Some Principles of Stratification, 10 Am. Soc. REv. 242,243 (1945).

205. See, e.g., GilbERT \& KAHL, supra note 202, at 43-44. In the early 1920s, F.E. Barr compiled the Barr Scale of 120 occupations, ranked zero to one hundred by a team of judges based on the degree of intelligence required to perform the job. DUNCAN ET AL., supra note 173, at 75 . Next, Otis Duncan provided an Index of Occupations, based on the 1960 Census, providing scores of zero to ninety-six based on income and education levels for each occupation. PETER M. BLAU \& Otis D. Duncan, The American Occupational Structure 120-23 (1967); see also id. at 26-27 (ranking 17 occupational groupings by a composite of median income and education, and noting that only in five of 27 instances do the education and income measures diverge). Other indicators exist, such as the Hollingshead Index of Social Position, which incorporates both education and occupation. See GILBERT \& KAFL, supra note 202, at 115. In addition, im 1947 and 1963, the National Opinion Research Center (NORC) polled average Americans on the relative occupational prestige of a number of professions. BLAU \& DUNCAN, supra, at 120-21. Although derived from three different sets of data, the results of these three studies correlate almost perfectly, the pecking order unambiguous. DUNCAN ET AL., supra note 173, at 77; see also BLAU \& DUNCAN, supra, at 119-20; GiLBERT \& KAHL, supra note 202, at 41 (noting that the correlation between the 1947 and 1963 scores was "virtually perfect $(0.99)$," and that there have been "virtually no changes in the rankings of occupational prestige since 1925"). The correlation between the NORC studies and the Duncan Index is 0.91 . Id. at 43.

The NORC found that opinions about the relative standing of occupations were the same in 1963 as they were in 1947 and 1925. "Whereas they had expected to see significant shifts in the relative prestige given various jobs," write sociologists Richard Sennett and Jonathan Cobb, "they found instead that over the course of two generations, despite a major depression and substantial changes in the occupational structure, Americans retained a relatively stable picture of what constitutes more prestigious and less prestigious work." Richard Sennetr \& Jonathan COBB, The Hidden INJURIES OF ClasS 221 (1973). In fact, Sennett and Cobb argne, the hierarchy of occupational roles today is roughly consistent with the analogous hierarchy in an ancient Indian myth of Purusha, upon which India's caste system is built. Id. at 226-27. In a somewhat different context, the government of India uses occupation as one of the major factors in determining which groups will receive "backward" status necessary for preferential treatment. See Witten, supra note 170, at 376-77. Sociologist Donald Trieman's cross-cultural study of sixty societies found a "remarkably high" correlation (0.8) in relative occupational prestige across all pairs of countries. GILBERT \& KAFL, supra note 202 , at 42 .

Likewise, the federal government has no problem classifying civil service jobs in clear fashion, grades 1-18. See Paul fussell, Class: a Guide Through the american Status System 21 (1983) (reporting government job grades from 1 (messenger) to 2 (mail clerk), 5 (secretary), 9 (chemist), 14 (legal adıninistrators), and 16, 17, and 18 (high-level administrators)). Nor does the 
There are, then, a range of viable options for ranking occupations.

\section{c. The Sophisticated Definition}

The more sophisticated definition of class would include not only income, education, and occupation, but also factors such as wealth, schooling opportunities, neighborhood influences, and family structure.

\section{i. Wealth}

While wealth will normally correlate with income, ascertaining net worth helps fill out the "snapshot" picture provided by income in a given year. On the high end, one can imagine the wealthy entrepreneur who happens to take a year off to travel as his son applies to college, placing his assets into capital growth funds with very little income. On the low end, looking at assets can be a rough proxy for whether a child once lived in poverty, and for how long. Whereas soine $20 \%$ of children may be poor in a given year, nearly $50 \%$ experience some poverty in their first eighteen years. ${ }^{206}$ A child might have lived in poverty for seventeen years, although his mother's job now places him in the middle class. Net worth, which accumulates over time, helps capture this phenomenon. In addition, African Americans generally have lower net worths than whites of the same income group, in part because of residential discrimination and less inherited "family" money, so including net worth in the calculus helps reflect that legacy as well. And measuring net worth does not pose any particular problem; it is already routinely disclosed in applications for student financial aid. ${ }^{207}$

Census Bureau have difficulty in establishing various occupational groupings. See BLAU \& DUNCAN, supra, at 23 (reporting 10 major occupational groupings under Census guidelines). The Bureau's rankings, devised in the 1940 s by Dr. Alba M. Edwards, factored in "the nature of the work, the skill and training involved in it, the income it brought, and common opinion about its prestige." See GLBERT \& KAHL, supra note 202, at 67. This basic scheme is still used today. See id. at 68-69. The Department of Labor, too, has an elaborate occupational code, which reflects relative status. Rose, supra note 190 , at 19 . The categories are

managers, professional and technical, administrative support and sales, skilled blue-collar, less skilled blue-collar, service, and farmers/farm laborers. Implicitly, the structure of this list reflects ideas of status. Various experts have examined the nature of various types of work and have conducted surveys on public attitudes toward different jobs. By looking at salary levels, whether the work is primarily manual or mental, how much control one has over one's work situation, and how much opportunity there is for advancement, each Id. occupation is ranked according to its desirabihty.

The Fair Labor Standards Act also makes a distinction between professional and nonprofessional positions with respect to the requirement of paying overtime. In addition, various court decisions carefully define who is a "supervisor." See Frank Swoboda, Ruling Could Narrow Labor Protections, WASH. POST, May 24, 1994, at D1.

206. Robert D. Reischauer, The Welfare Reform Legislation: Directions for the Future, in Welfare Policy FOR THE 1990s I0, 14 (Phoebe H. Cottingham \& David T. Ellwood eds,, 1989).

207. D'SouzA, supra note 84 , at 252 . While wealth by itself will not be a good divider-in 1983, the financial assets of more than half of all families were zero or negative-to ignore it 


\section{ii. Schooling Opportunities}

Broad empirical evidence suggests that the quality of one's primary and secondary schooling, including the quality of one's fellow students, has a major impact on educational achievement. While family background is extremely important to academic success, high concentration of poverty in a school has its own independent effect. Poor children start off behind in first grade. According to the National Assessment of Educational Progress, students in high poverty schools (76\%-100\% poor) score in the 33rd percentile on reading tests, while students in low poverty schools (0-19\% poor) score in the 60th percentile. ${ }^{208}$ By the eighth grade, however, the gap widens to 22 nd percentile for poor, and 65th percentile for rich. The same pattern holds for math. ${ }^{209}$ The data also show that poor children in schools with high concentrations of poverty are three times more likely to score in the bottom $10 \%$ nationally than poor children in schools with low poverty concentrations. Meanwhile, poor children in high poverty concentration schools are two times less likely to score in the top half than poor children in low poverty schools. ${ }^{210}$ More striking, however, are researchers Marshall Smith and Jennifer O'Day's findings that nonpoor students attending schools with high concentrations of poverty perform, on average, less well than poor children attending nonpoor schools. ${ }^{211}$

While it may seem impossible to rank schools by "quality," admissions officers at selective colleges have detailed knowledge about various high schools. ${ }^{212}$ As Dinesh D'Souza points out, accounting for school atmosphere "might seem an extraordinarily complex calculus," but "colleges already have access to, and in many cases use, this data." ${ }^{213}$ In order objectively to quantify school quality, a calculus could consider readily available figures, such as the percentage of students at each school who receive free or reduced price lunches, mean test scores on standardized tests, and/or per pupil expenditure. As an

altogether would be wrong. See George F. Will, What Dukakis Should Be Saying, WASH. PosT, Sept. 15,1988 , at A25.

208. Holly Holland, Schools Worried by Clusters of Poverty, CouRIER-J. (Louisville), Dec. 11, 1993, at A1, A16.

209. Id.

210. William L. Taylor, The Continuing Struggle for Equal Educational Opportunity, 71 N.C. L REv. 1693, 1703 (1993) (citing data from the Department of Education's National Assessment of Chapter 1, a federal program designed to assist economically disadvantaged students).

211. Id. at 1704 (citing Marshall Smith \& Jennifer O'Day, Educational Equality: 1966 and Now, in Spheres of Justice IN Education: The 1990 American Education Finance Association YEARBOOK 53, 74 (Deborah A. Verstegen \& James G. Ward eds., 1991).

212. See David OWen, None of the Above: Behind The Myth of Scholastic Aptitude 267-68 (1985).

213. D'SouzA, supra note 84, at 252. 
alternative, one might consider giving special consideration to students from high schools with low graduation rates. ${ }^{214}$

\section{iii. Neighborhood Influences}

Living in certain low-income communities can have a negative impact on an individual's life chances-an increased likelihood of dropping out of school, or of having an out-of-wedlock child-even when controlling for class. ${ }^{215}$ This is an additional burden that the underclass-those six percent of the poor living in highly concentrated poverty-face over those who are merely poor. ${ }^{216}$ One study in Chicago suggests that poor black students whose families reside in middle-class black or white suburban neighborhoods have a higher high school graduation rate than those remaining in lower-class neighborhoods (95\% vs. $80 \%$ ) and are more likely to go on to college (54\% vs. $21 \%$.). ${ }^{217}$ As with other criteria, there is some scholarly debate over the degree to which concentration of poverty and neighborhood influences affect life chances. ${ }^{218}$ But much evidence supports William Julius Wilson's thesis that neighborhood matters, ${ }^{219}$ and the debate should turn on how much weight to give this factor, not on whether it should count at all.

There are many ways to measure neighborhood influences objectively. The percentage of households living in poverty is the most common, but other possible indicators include median family income, male unemployment rate, and the percentage of female-headed households, each indicator measured by zip code or census tract. ${ }^{220}$ Others

214. See, e.g., Sarah Lubman, Campuses. Mull Admissions Without Affirmative Action, WALL ST. J., May 16, 1995, at B1, B4 (considering the use of graduation rates).

215. William Julius Wilson is especially noted for this hypothesis. See, e.g., Williarn J. Wilson, Another Look at The Truly Disadvantaged, 106 PoL. Sc1. Q., 639, 642 (1991-92) (discussing the effects of social isolation); see also Crane, supra note 194, at 317 (finding, for example, that the surge in childbearing and dropout probabilities in 1970 was the same for both white and black teenagers living in poor neighborhoods).

216. In 1980, according to Mickey Kaus, there were 31 million poor, of which only 1.8 million lived in tracts with $40 \%$ or more residents in poverty. MICKEY KaUs, THE END OF EQUALITY 105 06 (1992).

217. Douglas J. Besharov, Do We Have to Give Up?, Wash. Post, Oct. 23, 1994, at Cl, C4. In addition, participants im the housing desegregation program spurred by Gautreaux v. Chicago Housing Authority, 503 F.2d 930 (1974), are more likely to attend a four-year college (27\% vs. 4\%), and if not in college, are more likely to be employed full time (75\% vs. $41 \%$ ). From Ghetto To Suburb, Economist, Oct. 7, 1995, at 33.

218. See, e.g., Mayer \& Jencks, supra note 194, at 1441-43 (arguing the impact may not be as large as Wilson and others believe).

219. See Wilson, supra note 215 , at 651 (citing four studies supporting the negative effects of concentrated poverty).

220. See, e.g., Mary Corcoran et al., The Association Between Men's Economic Status and Thelr Family and Community Origins, 27 J. Hum. Resources 575 (1992) (using this zip-code methodology). One widely used definition of underclass census tracts looks at such factors as the proportion of high school dropouts, young males outside the labor force, welfare recipients, and 
have suggested looking at the crime rate in an area as a factor indicating disadvantage. ${ }^{221}$ One federal proposal to provide regulatory relief for distressed communities extends benefits to those census tracts with more than $33 \%$ of the population living in poverty, in which $45 \%$ of the outof-school males work less than 26 weeks in a year, where $36 \%$ of the families with children are headed by a smgle parent, or im which $17 \%$ of the residents receive public assistance..$^{222}$

\section{iv. Family Structure}

Within the sophisticated definition, the fimal factor to consider is family structure, by which I primarily mean the absence or presence of two parents, but which also might consider a parent's age. Singleparent families generally have lower family income; families headed by single mothers are six times as likely to be in poverty than all other American families. ${ }^{223}$ But as the United States Departınent of Labor noted in 1965, the tested IQ of children is lower when the father is absent, even after controlling for class. ${ }^{24}$ More recently, Sara McLanahan and Gary Sandefur, in their book Growing Up With A Single Parent, conclude that

children who grow up in a household with one biological parent are worse off, on average, than children who grow up in a household with both of their biological parents, regardless of the parents' race or educational background.... [A]dolescents who have lived apart from one of their parents during some period of childhood are twice as likely to drop out of high school, twice as likely to have a child before age twenty, and one and a half times as likely to be "idle"-out of school and out of work-in their late teens and early twenties. ${ }^{225}$

female-headed households. Erol R. Ricketts \& Isabel V. Sawhill, Defining and Measuring the Underclass, 7 J. PoL'y ANALYsis \& MGMT. 316, 322 (1988).

221. See, e.g., Sarah Lubman, UC Vote to Abolish Racial Preferences in Admissions Still Has Shades of Gray, WaLl ST. J., July 24, 1995, at A6.

222. See Revitalizing Hearings, supra note 183, at $87-88$ (statement of Marc Bendick, Jr., Ph.D., Project Director, Committee for Economic Development, New York, New York) (describing, inter alia, S. 1184, the Urban Regulatory Relief Act of 1995).

223. Bureau of the Census, U.S. Dep't of Commerce, Statistical abstract of the United States xiv, tbl. C (1992), cited in Richard J. Herrnstein \& Charles Murray, The Bell. Curve: InTElligence AND CLASS Structure IN AMerican Life 137 (1994). For families headed by single women, the poverty rate in 1991 was $36 \%$, compared with $6 \%$ for all other American families. Id.

224. Office of Policy Planning and Research, U.S. Dep't of Labor, The Negro Famly: The Case for National Action 35-37 (1965). This section of the Report dealt specifically with Negro children. See also Daniel P. Moynihan, A Family Policy for the Nation, 13 AMERICA 280, 281 (1965) (pointing out that ethnic groups that tend to have a stable and cohesive family life fare better economically and socially).

225. Sara Mclanahan \& Gary Sandefur, Growing Up With a Single Parent: What HURTS, What HeLPS I-2 (1994). 
While discussion of the subject was once taboo, today everyone, from former Vice President Dan Quayle to Secretary of Health and Human Services Donna Shalala, agrees that children who live with two parents have a better chance of making it in our society. ${ }^{226}$ As columnist E.J. Dionne Jr., explains, "This ought not be a complicated proposition. The fact is that raising children is an immensely time-consuming endeavor. Single parents have a tougher time of it than married parents do in large part because one person has exactly half the potential time available that two people do."227 But there is a second effect when a parent leaves rather than dies. "Psychologically, a kid is obviously better off knowing that he or she is important enough that both a father and a mother are willing to be there. What happens to your sense of self-worth if your father simply disappears?'228

Since family structure constantly changes, employing this criterion can be problematic. The parents of a child born out of wedlock may decide to marry. Intact marriages undergo separations and divorces; spouses may remarry or be widowed. Today, half of all American children will spend some time in a single-parent home before the age of $18,{ }^{229}$ though at any one time the figure is $25 \% .{ }^{230}$ Ideally, we want to know how long a child lived with one parent. Short of that, a line could be drawn between children living with one parent whose parent never married (50\%) and children of divorce (50\%), with the former being more disadvantaged. ${ }^{231}$ In addition, one might consider the age of the child's parents, since there is a disadvantage to being born to a mother still herself a mimor.

Some will find the notion of rewarding out-of-wedlock birth, divorce, or teenage childbirth abhorrent. ${ }^{232}$ However, the preference goes not to the parent, but to the child who has faced an additional impediment not of her own inaking. Furthermore, it is absurd to say that preferences for the child will somehow provide an incentive for mothers to have out-of-wedlock births. A pregnant teenager bringing a child into

226. See, e.g., Dan Balz, Quayle Revisits Old Theme in Speech About U.S. Values, WASH. POST, Sept. 9, 1994, at A4 (describing Shalala's testimony before Congress).

227. E.J. Dionne Jr., Bill \& Dan \& Murphy Brown, WASH. Posr, Sept. 13, 1994, at A21.

228. Id.

229. Douglas J. Besharov, Broken Family Values, WASH. Post, Jan. 15, 1995, Book World, at X4; see also DAvid T. Ellwood, POOR SUPPort: POVERTY IN THE AMERTCAN FAMILY 45-46 (1988).

230. Nearly three-quarters of children live in an arrangement that includes two parents, married or unmarried, biological or nonbiological. Barbara Vobejda, Study Alters Image of Typical Family, WASH. Post, Aug. 30, 1994, at A3.

231. See More Children Being Born to Unwed Parents, Study Says, Wash. Post, July 20, 1994, at A3 (describing children living with a parent who had never been married as "radically fatherless").

232. See, e.g. Michael Kinsley, The Spoils of Victimhood, NEw YORKER, Mar. 27, 1995, at 62, 66; Interview with Dinesh D'Souza (Dec. 19, 1994). 
the world without a husband is unlikely to be thinking hard about maximizing her child's life chances, much less the idea that eighteen years down the road the child will have a small edge at getting into Harvard.

\section{d. The Sophisticated Definition Should Be Favored}

Of the three definitions, the sophisticated one is the fairest, and should be employed whenever practical. Its use is most compelling in the context of university admissions, where admissions officers already have access to a wealth of information. The more factors imcluded in the process, the less likely an applicant will successfully manipulate the system, or commit outright fraud. In entry-level employment, by contrast, a more simple definition of class may suffice, since employers generally do not have access to the same data as universities.

A seven-part test of disadvantage will inevitably be ridiculed by . those who favor inaction. First, some will say that you cannot assign a number to disadvantage. At some philosophical level, this is surely true. However, the same could be said of intelligence or intellectual promise, and yet universities quantify such intangibles every year when they come up with index scores based, for example, on GPAs and LSAT scores. Some critics always greet new proposals for social progress as "Orwellian." Yet, the system in use today is more truly Orwellian: having a teenager take a three-hour standardized test and then having that number stick with her, without controlling for disadvantage. Accounting for disadvantage just makes deciding who gets ahead and who does not a little more fair.

Second, some may argue that, even though class-based preferences are more fair, sorting by race is simply easier. But this argument ignores the difficult ambiguities associated with racial preferences. Consider, as just one example, the unpleasant task of deciding which individuals can properly claim to be members of the preferred minority group. ${ }^{233}$ According to a study by the National Center for Health Statis-

233. Critics note that sometimes it is difficult to tell by sight whether a person is black or white. When Vanessa Wilhams was crowned the first black Miss America in 1984, many viewers thought she was white. F. James Davis, Who ls Black? One Nation's Definition 2 (1991). Adam Clayton Powell, Jr., the black Congressman from New York, says in his autobiography that his freshman roommate at Colgate did not know he was black until his father came to campus, at which time the roommate declared an end to their friendship. Id. at 2. In 1984, in Stockton, California, Ralph White, a black businessman, accused a competing candidate for a city election, Mark Stebbins, of saying he was a black candidate when in fact he was white. See Neil Gotanda, A Critique of "Our Constitution Is Color-Blind," 44 STAN. L. REv. 1, 24 n.93 (1991). The very notion of "passing"-or, today, "reverse passing"- -would not be possible if race were not, on the margins, mutable. See Cheryl I. Harris, Whiteness As Property, 106 HARv. L. REv. 1707, 1712 n.6 (1993) (discussing recent incidents of individuals "reverse passing" as members of an ethnic minority group in order to benefit from affirmative action programs). 
tics, nearly one-third of those who called themselves Asians were identified by independent observers as black or white, $70 \%$ of American Indians were so identified, and $5.8 \%$ of those who self-identified as black were characterized as white by a census observer. ${ }^{234}$ Another study by the Centers for Disease Control and Prevention found that an "astounding number" of infants who died had different races designated on their birth and death certificates. ${ }^{235}$ Race-based affirmative action programs also raise tricky questions about which ethnic groups should benefit and whether recent immigrants should qualify. ${ }^{236}$

In the end, proponents of affirmative action should be especially wary of using the argument of complexity against class preferences. Racial preferences are just as easy to criticize. To paraphrase Kinsley, does a new Indian immigrant get fewer or more points than a thirdgeneration Latino whose mother is Anglo?237

Finally, even to the extent that sorting by race might seem easier than looking to individual disadvantage, that should not be the ultimate measure. As Justice Douglas noted in DeFunis, "we have never held administrative convenience to justify racial discrimination."238 While an

234. See Lawrence Wright, One Drop of Blood, NEw Yorker, July 25, 1994, at 46, 53.

235. Id. Furthermore, critics point out, when race or ethnicity is contested, one must ultimately turn to the types of identification rules employed in Nazi Germany, in South Africa, or in the American South. See, e.g., Metro Broadcasting, Inc. v. FCC, 497 U.S. 547, 633 n.1 (1990) (Kennedy, J., dissenting) (citing South African regulations), overruled in part by Adarand Constructors, Inc. v. Pena, 115 S. Ct. 2097 (1995); Fullilove v. Klutznick, 448 U.S. 448, 534 n.5 (1980) (Stevens, J., dissenting) (citing Nazi guidelines for defining Jews); Regents of the Univ. of Cal. v. Bakke, 438 U.S. 265, 297 n.37 (1978) (Powell, J.) (citing Plessy v. Ferguson, 163 U.S. 537, 549, 552 (1896), overruled by Brown v. Board of Educ., 347 U.S. 483 (1954)). Critics point to the absurdity of our historical rules of racial identification: from North Carolina's rule that "any visible admixture of black blood" makes one black, to Ohio's use of a "preponderance of blood" measure, to the requirement, in Michigan and Virginia, that three-quarters white blood was necessary to qualify as white. See Plessy, 163 U.S. at 552 (citing all three methods of racial categorization). As Yehudi Webster points out, "One's race could be changed by crossing state lines." Yehudi Webster, The Racialization OF AMERICA 34 (1992).

Louisiana employed the "one drop" rule until 1970, when it changed the law in response to a lawsuit brought on behalf of a child said to be $1 / 256$ th black. DAvIs, supra note 233 , at 9 . Then, in the early 1980s, when Susie Phipps, the great-great-great-great-granddaughter of a mixed union sued to declaro herself white, the Louisiana courts held that although she was less than $10 \%(3 / 32)$ black, and although she never held herself out to be black, she was by law black. Id. at 10. The U.S. Supreme Court declined to disturb the ruling "for want of a substantial federal question." Id. at 11; see also Deborah A. Ramirez, Multicultural Empowerment: It's Not Just Black and White Anymore, 47 STAN. L. REv. 957, 964-69 (1995) (claiming that the "one-drop rule" incidentally fostered a pervasive American belief that all individuals belong to one group or another). Interestingly, one of the early affirmative action programs, employed by the University of Washington Law School in the program contested by Marc0 DeFunis, appeared to use a sort of blood quantum test-whether the applicant had a "dominant" ethnic origin of black, Chicano, American Indian, or Filipino. DeFunis v. Odegaard, 416 U.S. 312, 320 (1974) (Douglas, J., dissenting).

236. See KAHLENBERG, supra note 104, at 137-39.

237. See Kinsley, supra note 232, at 66 (claiming that distinctions based on class are unworkable).

238. DeFunis, 416 U.S. at 341 (Douglas, J., dissenting). 
admissions committee might be able to sort more quickly by race than class, Temple University President Peter Liacouras has reminded us: "What part of a faculty or administrative member's work is as socially important as to decide fairly who will share in the American Dream . . . ?"239

\section{Defining The Limits of Class-Based Preferences}

What should be the cutoff for beneficiaries? For instance, should only the underclass benefit, or working-class teenagers as well? Should the upper-middle class benefit vis-a-vis the rich? Should the cut-off depend on the context? Taking the last question first, it clearly makes sense to provide a relative cutoff depending on the context. The poverty line is an absolute standard (the cost of feeding a family multiplied by three).$^{240}$ But since the goal is to provide genuine equal opportunity in life's race, a class-based program should correct for relative inequality of opportunity. For example, a metropolitan police force may recruit primarily from working-class cominunities, in which case the preference should go only to those from poor families who lack comparative equality of opportunity. By contrast, applicants to elite colleges may be predominantly wealthy and upper-middle class (with almost no poor applicants), in which case a working class applicant is relatively disadvantaged. As a practical matter, it may be impossible to find enough students in abject poverty who, even with a remedial program, will be capable of doing the work at an elite university. At Berkeley, for instance, students who met the strict requirements of the Educational Opportumity Program-neither parent attended a four-year college, and parents could not afford to pay more than $\$ 1000$ in educational expenses-often did not have the grades and board scores to indicate likely success. Accordingly, Berkeley determined that its socioeconomic measure of disadvantage had to be broadened, that it needed to redefine "socioeconomic[] disadvantage[] in the Berkeley context." ${ }^{241}$ Berkeley established a two-tier system, with a sizable preference for students from families of four with income below approximately $\$ 23,000$, and a smaller preference for students with family income between $\$ 23,000$ and $\$ 33,000$ (the state median). ${ }^{242}$

In constructing a relative cutoff, there are at least two powerful reasons to provide benefits to more than those at the very bottom of society. First, the injuries of class extend beyond the very poorest. The

239. Peter J. Liacouras, Toward a Fair and Sensible Policy for Professional School Admission, 1 Cross Reference 156, 162 (1978).

240. ElLwOOD, supra note 229, at 82.

241. CoMmittee on ADMissions AND ENROLLMent, supra note 157, at 45.

242. Laird Interview, supra note 157. 
offspring of the working poor and the working class lack advantages, too; indeed, SAT scores correlate lockstep with income at every increment. Allan Nairn, author of a study on the Educational Testing Service, notes:

It is not simply a inatter of penthouse versus tenement. The ETS score discriminates not only between the rich and a minority of Americans (the very poor) but also between the rich and a $m a-$ jority of Americans (the members of the working and middle classes). The SAT discriminates among virtually all levels of the country's class structure-across both incoine and occupation. The more money a person's family makes, the higher that person tends to score; people from homes with $\$ 21,000$ incomes tend to score higher than people from homes with $\$ 18,000$ incomes; people from white collar hoines tend to score higher than people from blue collar hoines. ${ }^{243}$

Likewise, social mobility studies find that the rich have enormous advantages over the middle class, that children born to the top five percent are twenty times more likely to be wealthy than children born at the median income. ${ }^{244}$ These statistics suggest unfairness is not confined to the underclass.

Second, as a political matter, a program aimed only at the very poor, while perhaps more politically viable than one that is race-specific, is still less viable than one with a broader base of beneficiaries. After analyzing the history of social prograins in the United States, Harvard Professor Theda Skocpol comes to three general conclusions:

First, when U.S. antipoverty efforts have featured policies targeted on the poor alone, they have not been politically sustainable, and they have stiginatized and demeaned the poor. Second, some kinds of relatively universal social policies have been politically very successful. Third, room has been made within certain universal policy frameworks for extra benefits and services that disproportionately help less privileged people without stigmatizing them. What I shall call "targeting within universalism" has delivered extra benefits and special services to certain poor people throughout the history of modern American social provision, and new versions of it could be devised today to revitalize and redirect U.S. public social provision. ${ }^{245}$

243. NAIRN, supra note 167 , at 200.

244. Richard H. De Lone, Small Futures: Children, InequaltTy, and the limits of Liberal Reform 209 n.l (1979) (citing John A. Brittain, The Inheritance of Economic STATUS (1977)).

245. Theda Skocpol, Targeting Within Universalism: Politically Viable Policies to Combat Poverty in the United States, in ThE URBAN UNderClass, supra note 194, at 411,414; see also Paul Starr, Civil Reconstruction: What to Do Without Affirmative Action, AM. Prospect, Winter I992, at 7, 8 (noting that measures "for minority groups or the poor alone" tend to be poorly funded). 
Skocpol's thesis has been criticized by those who point out that universal programs are inore expensive than targeted ones. This argument applies with less force to preferences, so broadening the group of beneficiaries makes good political sense. ${ }^{246}$

A middle ground might provide a sliding scale of preferences in which a substantial preference goes to those who are at one-half the inedian socio-economic status in the applicant pool and below, and a smaller preference to those between one-half the inedian and the median itself. ${ }^{247}$ The one-half-the-median guidelme is a well-established measure of disadvantage einbraced by, among others, the philosopher John Rawls. In defining "the least fortunate group," Rawls says the one-half median inark (of wealth and income), though arbitrary, "has the merit of focusing attention on the social distance between those who have least and the average citizen." 248

Providing a moderate preference for those above this line, or perhaps even for those up to the inedian, will strike many readers as too generous. But in 1994 , median family income was just $\$ 32,264,{ }^{249}$ and as of 1982 , families living below the median shared in only $20 \%$ of the nation's incoine. ${ }^{250}$ Before becoming too concerned about a student at the 49th class percentile receiving a boost, consider that, in $1991,60 \%$ of American households did not buy a single book all year, ${ }^{251}$ and that only $2 \%$ of books bought were "serious" books. ${ }^{252}$ Consider also that

246. See, e.g., Robert Greenstein, Universal and Targeted Approaches to Relieving Poverty: An Alternative View, in THE URBAN UNDERCLASS, supra note 194, at 437, 438.

247. In fact, one federal program now provides a two-tiered preference, with one preference for very low income (income below 50\% of the median) and another preference for low income (those with incomes between $50 \%$ and $80 \%$ of the median). Adjustments are also made for smaller and larger families. See U.S. Housing Act of 1937, 42 U.S.C. § 1437a(b)(2) (amended 1990).

248. See JOHN RAwLS, A THEORY OF JUSTICE 98 (1971). In academic parlance, the measure is known as the "Fuchs" criterion, named for one of its proponents, Victor Fuchs. See DaNIEL BeLL, The Coming of Post-Industrial Society 446 n.97 (1973) (citing Victor R. Fuchs, Redefining Poverty and Redistributing Income, PUB. INTERest, Summer 1967, at 88). As an alternative, one can measure deprivation in terms of half the average or mean income, a criterion generally accepted both by economists and laymen. ARThur M. OKUN, EQUALITY AND EFFiciency: The Big TRAdeOFF 95 (1975). Polling has shown that Americans have for decades defined poverty as half the average income-irrespective of what the average income is. Christopher Jencks, INEQUALITY 4 (1972). This is true even though mean income doubled over 30 years. Indeed, when drawing up the federal poverty line, Jencks says the Johnson Administration deliberately set the poverty line lower than one-half the average income, so that "even conservatives would admit that those below the line were poor." Id. at 5 .

249. Barbara Vobejda, U.S. Reports Decline in Number of Poor, WASH. PosT, Oct. 6, 1995, at A1, A10.

250. Lester C. Thurow, The Zero-Sum Solution: Building a World-Class American ECONOMY 110 (1985).

251. Robert Hughes, Culture of Complant: The Fraying of America 103 (1993).

252. Hal Crowther, In a Dying Culture, Thank God for Snobs, WAsH. Post, Aug. 27, 1995, at G1, G7. 
$75 \%$ of American workers have not completed college, and $93 \%$ do not have more than two years of schooling beyond a bachelor's degree. ${ }^{253}$

Indeed, there is nothing sacred about providing special benefits only to those below the poverty line. The Earned Income Tax Credit, which has broad public support, provides working families earning up to $\$ 26,673$ per year with tax relief, and is slated to cover $45.1 \%$ of families in Mississippi and $42.3 \%$ of families in the District of Columbia in 1996..$^{254}$ Likewise, when health care reform was debated in 1994, a group of Senate moderates, dubbed the "mainstream" coalition, supported health care subsidies for families earning up to $240 \%$ of the poverty line..$^{255}$ In 1994, that translated into benefits for a family of four earning $\$ 36,338$ - a figure higher than the national median. ${ }^{256}$

A failure to provide some preference up to the median would mean that those between one-half the median and the median itself were likely to bear the brunt of the preference. The poor would receive a break, the middle and upper class would continue to enjoy advantages, and the lower-middle class would be squeezed. Furthermore, a sliding scale may be implemented in the class context with much greater ease than in a race system. While it is difficult to calibrate the difference between discrimination against African Americans and Asians, socio-economic status, which falls neatly on a continuum, does not present this same challenge.

\section{Implementing A Class-Based Affirmative Action Program}

How would a class-based affirmative action program be implemented? Would it be voluntary or mandatory? Would it apply to the public sector, the private sector, or both?

The basic legal framework in which race-based affirmative action is currently grounded provides a good starting place for the implementation of class-based preferences. The underlying philosophy is that those in the private sector (universities or employers) should not be required to provide preferences, but that those who choose to receive federal funding or benefit from federal contracts can rightly be held to a higher standard. In addition, indirect incentives can be used to encourage private employers to consider class preferences as a way of com-

253. Barry Bluestone, The Inequality Express, AM. ProspeCt, Winter 1994, at 81, 83-84.

254. See Internal Revenue Service, U.S. Dep't of The Treasury, Form 1040, at 5 (1995); James Bovard, Clinton's Biggest Welfare Fraud, WAll St. J., Apr. 10, 1994, at A18; Michae1 Kinsley, Let Them Eat Laptops, New Yorker, Jan. 23, 1995, at 6, 7. In the 1994 tax year, the earnings capwas $\$ 25,296$. The 1996 eamings cap is slated to be set at $\$ 28,524$. Steven Pearlstein \& Edward Walsh, Tax Credit for Poor Comes Under Attack, WASH. Post, July 30, 1995, at A1, A8.

255. David Rogers, Senate Moderates Move to the Right, Scaling Back Compromise Health Plan, WALl St. J., Aug. 19, 1994, at A12.

256. The poverty line in 1994 for a family of four was $\$ 15,141$. Vobejda, supra note 249 , at Al. 
plying with the racial balancing requirements of the Civil Rights Act of 1991.

\section{a. The Federal Government}

First, the federal government should take the lead by providing preferences to qualified disadvantaged applicants in its own entry-level employment. Federal managers would be required to set goals for entry-level hiring, and would need to have a strong jnstification for failing to meet the goal. Preferences would not be employed for promotions, since the goal is not preferences as a way of life, but rather preferences as a means for providing disadvantaged young people with a chance to prove themselves.

\section{b. Institutions Receiving Federal Aid}

Second, institutions receiving federal aid could, as a condition of receipt, be required to provide reasonable class-based preferences in entry-level hiring and student admissions. This requirement would bring almost all universities and state and local government institutions within the preference program. Those institutions not wishing to employ preferences would not be forced, but would forfeit federal aid. ${ }^{257}$

Dictating university admissions in this manner, rather than relying on voluntary preferences, is not a threat to academic freedom as we know it. Title VI of the Civil Rights Act already prohibits universities receiving federal funds from discriminating against racial minorities. ${ }^{258}$ Likewise, the Civil Rights Act's employment discrimination requirements, which initially exempted universities, now apply to them, arguments of "academic freedom" notwithstanding. ${ }^{259}$ University decision Inakers who feel strongly that they should not give preferences to poor and working class students, or who wish to discriminate against racial minorities, would be free to follow their choices, but the federal government need not subsidize such decisions.

Requiring class preferences appears necessary because most universities are unlikely to provide them on their own. Some universities purport to count disadvantage informally as a plus in admissions (Harvard,

257. In the context of race, Richard Kluger notes that the passage of federal funding of schools through the Elementary and Secondary Education Act of 1965 provided "the government with a mighty financial clnb to enforce compliance with the desegregation orders of federal courts." RiCHARD KLUGER, Simple Justice 759-60 (1975).

258. Title VI is the mechanism through which institutions such as Harvard had to open np their admissions processes to federal investigators looking at the question of discrimination against Asian Americans. See U.S. Dep't of Educ., supra note 163. In Bakke, four members of the Court said Title VI also forbade racial discrimination against whites. 438 U.S. at 418 (plurality opinion) (Stevens, J.). A majority of the Bakke Court found that Title VI prohibits quotas. Id. at 287, 307 (Powell, J.).

259. See Alan H. Goldman, Justice ANd Reverse Discrimination 204 (1979). 
im the Bakke case, said it preferred "disadvantaged economic, racial and ethnic groups,"260 and New York University's law school includes in its diversity considerations a category for "socio-economic condition"261). Nevertheless, the class preference most universities employ today is for the wealthy.

When researchers compare prep school students with public high school students who have the same SAT scores, they find that the advantaged private school students have "a significant edge in admissions" at Ivy League and other prestigious colleges. ${ }^{262}$ Indeed, one study comparing a leading selective public high school with sixteen elite boarding schools found that students at the boarding schools were twice as likely to get into Harvard, Yale, and Princeton, even though students at the public high school had SAT's averaging 150 points above those of students at leading boarding schools. ${ }^{263}$ Even within the alumni legacy category, those who do not apply for financial aid have a higher rate of acceptance at Harvard than those legacies who do. ${ }^{264}$

In the Harvard class of 1975, for which data is public, no preference was given for disadvantaged students, but, even if grades and test scores were held constant, being an alumni child boosted one's chances of acceptance by $33 \%$, and being from a private school boosted chances by $10 \%{ }^{265}$ Other schools varied in their approach to disadvantage: at Williams and Colgate, disadvantage slightly improved one's chances of being admitted, while at Bucknell, it hurt slightly. In all cases, racial and alumni preferences, were far more important. ${ }^{266}$

If universities were employing aggressive class preferences todayon the theory that poor and working class students add diversity or show greater potential than advantaged students with the same scoresdisadvantaged students would have a higher rate of acceptance when

260. Bakke, 438 U.S. at 322 (appendix to opinion of Powell, J.).

261. SCHWARTZ, supra note 38 , at 155 .

262. Peter W. Cookson, Jr. \& Caroline H. Perseld, Preparing for Power: America's Elite BoARding Schools 167-89 (1985), cited in Paul W. Kingston \& Lionel S. Lewis, Introduction: Studying Elite Schools in America, in The High Status Track: Studies of Eutte Schools and Stratimication xii (Paul W. Kingston \& Lionel S. Lewis eds., 1990) [hereinafter The High Status Track].

263. Caroline H. Persell \& Peter W. Cookson, Jr., Chartering and Bartering: Elite Education and Social Reproduction, in THE High STATUS TRACK, supra note 262, at 25, 33. Persell and Cookson compared the acceptance rates of students at 16 select boarding schools (Andover, Exeter, St. Paul's, Groton, etc.) and an unnamed selective public high school.

264. Jerome Karabel \& David Karen, Go to Harvard; Give Your Kid a Break, N.Y. TIMEs, Dec. 8,1990 , at 23 .

265. Robert Kuitgaard, Choosing Elites 28 (1985).

266. At Williams, being disadvantaged boosted chances $18 \%$, being a minority boosted chances $53 \%$, and being an alumni child boosted chances $36 \%$. At Colgate the numbers wcre $6 \%$ for disadvantage, $46 \%$ for minority status, and $31 \%$ for alumni status. At Bucknell, being disadvantaged decreased one's chance of acceptance by $1 \%$, while being a minority boosted chances $51 \%$, and being a legacy boosted chances $47 \%$. Id. at 46 . 
one controls for test scores. In fact, the opposite occurs. James C. Hearn found that $35 \%$ of the exceptionally able high-income students ( $\$ 38,000$ or more) attended highly selective colleges, while only $10 \%$ of exceptionally able lower-mcome students ( $\$ 16,000$ or less) attended a highly selective college. ${ }^{267}$ Overall, in 1986, when the national median family income was $\$ 28,000$, only one in twelve students at highly selective private colleges came from families with incomes below $\$ 20,000$. By contrast, in 1984, while only $20 \%$ of American families made above $\$ 50,000$, more than $50 \%$ of the families of those elite freshmen did. $^{268}$

Part of the problem may be latent class prejudice. ${ }^{269}$ But most of the reason that universities fail to give preferences to the poor, and indeed give hefty preferences to the rich, has to do with financial considerations. Government grants and loans rarely make up the entire shortfall at expensive private schools (or even at some public schools), which means the schools must make up the difference. ${ }^{270}$ The problem is likely to get worse, as more and more colleges abandon "needblind" admissions, as Brown University did in the early 1990s. By 1994, there were reportedly fewer than twenty schools with need-blind admission policies. ${ }^{271}$

Even racial preference programs fail to add much economic diversity. All the incentives point in one direction: a college can score as many diversity points for admitting advantaged people of color as less advantaged minorities, while avoiding the financial costs of providing aid. Universities gam no similar cachet for admitting poor and working-class white students, and since any preference ineans lower SAT medians (and lower prestige), schools understandably shy away from highly expensive preferences for poor students. ${ }^{272}$

If universities are required to provide class-based preferences, they will obviously want to negotiate to have the federal government pick up part of the tab for remedial education and financial aid for the increased number of poor and working-class students. The elimination of racial

267. James C. Hearn, Pathways to Attendance at the Elite Colleges, in THE High STATus TRACK, supra note 262, at $121,130$.

268. Kingston \& Lewis, supra note 262 , at xii.

269. As James Fallows points out, following World War II, educators at elite universities were horrified at the idea of accepting masses of students under the GI Bill, but the 2.3 million veterans "turned out to be phenomenally successful." James Fallows, MORE Like Us: MAKING AMERICA GrEat AGAIN 158-59 (1989).

270. Albert B. Crenshaw, The New College Criteria: Savings Rank With SATs, WaSH. PosT, June 26, 1994, at $\mathrm{H} 1, \mathrm{H} 4$.

271. Many believe the 20 school figure is too high. See id. at H4.

272. For evidence of the degree to whicb colleges aspire to high median SAT scores, see Steve Stecklow, Colleges Inflate SATs and Graduation Rates in Popular Guidebooks, Wall ST. J., Apr. 5, 1995, at A1. 
preferences should be traded for increased funding of higher education, to the benefit of poor and working-class people of all races.

\section{c. Federal Contractors}

Third, private companies doing business with the federal government (at least those with more than $\$ 50,000$ in contracts or having more than fifty employees) could be required to provide class preferences in entry-level positions, just as such companies are currently required to provide racial preferences under federal affirmative action guidelines. ${ }^{273}$ These rules cover $42 \%$ of the private work force. ${ }^{274}$ As with the current program, companies not reaching their hiring goals would risk losing federal contracts. ${ }^{275}$ Agani, to help share the cost of providing preferences, federal contractors may wish to seek more generous grants for any extra remedial training necessary for disadvantaged entry-level hires. ${ }^{276}$ In addition, to shift some of the burden of administration to the

273. Executive Order No. 11,246 and Revised Order No. 4-the major affirmative action requirements for federal contractors-do not explicitly require preferential hiring, but they do in practice, at least to some degree. For example, the government requires federal contractors to set goals and timetables for hiring "underutilized" minorities, and contractors must make "good faith efforts" to meet the goals. Indeed, in upholding the legality of the Philadelphia Plan, which was promulgated pursuant to Executive Order No. 11,246, the Third Circuit Court of Appeals specifically noted that Title VII's prohibition in $\S 703(\mathfrak{j})$ against using preferences to achieve a balanced work force did not apply to the Executive Order. Contractors Ass'n. v. Secretary of Labor, 442 F.2d 159, 172 (3d Cir. 1971), cert. denied, 404 U.S. 854 (1971). See also Thomas B. Edsall \& Mary D. Edsall, Chain Reaction: The Impact of Race, Rights, and Taxes on American Politics 86 (1991) (discussing the Philadelphia Plan).

However, "good faith" efforts under Executive Order No. 11,246, while requiring some preferences, may not mandate "significant" preferences. For example, the Citizens' Commission on Civil Rights, a group that strongly endorses affirmative action, notes in regard to implementing Executive Order No. 11,246 that if "the white candidates are significantly better qualified than the minority candidates, an employer may fail to meet its goal with impunity." Cirrzens' Commission oN Civil Righrs, supra note 149, at 68.

The difference, then, between what is required under Title VII and Executive Order No. 1I,246 is subtle, but very important. Both look at results, and both allow an escape hatch if the numbers don't work out right. But Title VII's escape hatch is larger: so long as the employer's hiring is justified by business necessity, no preferences are required. Under Executive Order No. 11,246, the "good faith" exception in effect requires preferences, just not "significant" ones. This distinction parallels President Clinton's distinction between preferences for the unqualified (bad) and preferences for the less qualified (good).

274. Peter Brimelow \& Leslie Spencer, When Quotas Replace Merit, Everybody Suffers, FORBES, Feb. 15, 1993, at 80, 82.

275. While those failing to meet goals could continue doing business with the federal government if they made good faith efforts, those efforts would be judged with reference to the availabihity of qualified applicants, not the most qualified applicants. That is to say, a mild preference would be required.

276. The form of such incentives is already being debated. See, e.g., Guy Gugliotta, Subsidy for Hiring Poor Under Review, WASH. POST, Nov. 28, 1993, at A6 (reporting that the Clinton administration is considering paying wage supports to companies that hire welfare recipients); Frank Swoboda, Reich Targets Several Job Programs, WASH. POST, Jan. 28, 1994, at A1 (reporting that the Secretary of Labor is targeting for extinction tax credits for employers who hire disadvantaged workers). 
government, employers may wish to push for a program under which graduating high school students who wish to benefit from a class preference must fill out a standard form providing readily accessible data, such as the identity of a student's high school, her place of residence, family structure, and parental income. ${ }^{27}$

\section{d. The Purely Private Sector}

In the purely private sector-companies not doing business with the federal government-current racial affirmative action requirements generally do not apply. Indeed, Title VII specifically says that preferences are not required under the Civil Rights Act. ${ }^{278}$ However, all employers with over fifteen employees (covering $86 \%$ of the nonfarm private-sector work force) $)^{279}$ are required to justify racial imbalances under the Griggs disparate-impact analysis. ${ }^{280}$ In practice, many private employers choose not to defend hiring practices that result in a racially unbalanced work force and instead use preferences to make sure their numbers work out. The Supreine Court provided some support for this general practice in the 1979 case of United Steelworkers $v$. Weber. ${ }^{281}$ But if Weber is overturned by the Court ${ }^{282}$ or if racial preferences are outlawed-some employers might find an incentive to use nonracial class preferences, which would disproportionately benefit minorities, as a way of avoiding disparate impact litigation. Under this plan, Griggs itself would not be repealed, so the pressure for class preferences would be indirect, since a "business necessity" defense would still work to explain disparities. Those employers who today use racial preferences to avoid lawsuits, and are no longer able to do so legally, might very well turn to legal class preferences instead. ${ }^{283}$

277. A family tax return, proving much of this information, could be attached. Net worth would not be requested. Those who are concerned about privacy would not be required to complete the form but would lose the opportunity of qualifying for a preference.

278. Title VII, 42 U.S.C. $\$ \S 2000 \mathrm{e}-2000 \mathrm{~h}$ (1994). There is an exception to this rule when preferences are ordered as a remedy for proven past discrimination by the employer.

279. Brimelow \& Spencer, supra note 274, at 82.

280. Griggs v. Duke Power Co., 401 U.S. 424 (1971).

281. 443 U.S. 193 (1979).

282. Commentators have questioned the viability of Weber for some time. See, e.g., DAviD A Cathcart et al., The Civil Rights Act of 1991 34-36 (1993) ("Weber and Johnson [v. Transporation Agency] may no longer be good law."); Don Munro, The Continuing Evolution of Affirmative Action Under Title VII: New Directions After the Civil Rights Act of 1991, 81 VA. L. REv. 565, 567-68 (1995):

Judicial antipathy toward affirmative action has put considerable stress on the two landmark cases of United Steelworkers $v$. Weber and Johnson v. Transportation Agency, which have served as the doctrinal basis for the modern law of voluntary remedial preferences in employment. Especially at the Supreme Court level, it is conceivable that a serious effort to limit or even prohibit racial preferences may arise in the near future.

283. See Munro, supra note 282 , at 602,610 . 


\section{Determining the Weight of the Preference}

How much of a preference should disadvantaged applicants receive? Under a voluntary "class-plus" system, how large should the plus be? Under a government system of goals, what is a reasonable target? If a college or government employer misses its target, what gap in traditional criteria is a reasonable excuse?

At one extreme, we can imagine a quite aggressive preference system, in which all economic groups in the general population (or, at least, the applicant pool) must be proportionately represented at a university or in an employer's entry-level workforce, so long as all those admitted or hired are minimally qualified to do the work. There would be debate over what "minimally qualified" is, but most universities now have a fairly good idea of how far down they can reach before the chances of failure grow too high.

At the other extreme, one can imagine a very small plus that would correct merely for the degree (if at all) to which grades and board scores underpredict the actual performance of students as reflected in first-year college grades. If this were the case, the size of the preference would be empirically tested against the grades earned at the university (or an employer's evaluation). If the preferred group had a median first-year GPA below the median of the nonpreferred, we would say that the preference was too large and should be adjusted.

Again, a middle ground between the extremes seems most appropriate. First, class preferences will not be able to make up for the entire social deficit, and, therefore, proportional representation is too ambitious a goal. Some naturally bright poor children do not live up to their potential because they have internalized certain values associated with the so-called "culture of poverty" (present-day orientation, weak work ethic, etc.). This handicap will limit their long-run potential in life. They may naturally be smart, and even work fairly hard compared to their more immediate peers, but insofar as they apply themselves less than their more advantaged peers, their long-run potential is stunted. Furthermore, to the extent that even a naturally bright and personally driven child has had an abysmal education and is completely unprepared for rigorous study, there are limits to the preference, since it is cruel to admit a child who has no chance of succeeding to Harvard or some other elite university. Admitting students who would be unlikely to perform adequately does no one any good.

Second, if the goal is to give a chance to those who have the greatest long-run potential, then the preferences need to be larger than a mere correction for underprediction of first-year grades. Eighteen years of poor preparation will not be made up overnight. As Justice Douglas argued in the context of a law student admitted on a class pref- 
erence, the applicant "may not realize his full potential in the first year of law school, or even in the full three years, but in the long pull of a legal career his achievements may far outstrip those of his classmates whose earlier records appeared superior by conventional criteria."284

Using input from universities and employers, reasonable goals should be set-short of proportional representation, but with greater representation than we see today. Universities that fail to meet their goals would have to justify why they could not find qualified applicants. Putting some pressure on universities to increase their numbers should result in aggressive recruitment of qualified but disadvantaged students who now either do not attend college or attend institutions below their potential. $^{285}$ In addition, regulations could effectively require remedial programs by saying that the failure to meet a goal is justified only if a remedial program was tried.

In education, carefully crafted remedial programs can be highly effective. At Georgia Tech, for example, the Challenge Program, a nonrace-based five-week program prior to freshman year, has been extremely successful in boosting minority achievement. In 1992, ten percent of African-American and Hispanic students received a perfect 4.0 grade point average-double the proportion of whites. ${ }^{286}$ The absolute number of blacks and Hispanics with $4.0 \mathrm{~s}$ in 1992 exceeded the total number for the period 1980 to 1990 , before the remedial program was revamped to encourage higher expectations and to reach members of all races. $^{287}$

According to Professor Leslie Espinoza, intensive in-residence summer programs for law schools run by the Council on Legal Educational Opportunity (CLEO) produce graduation rates of almost eighty percent, which is "remarkable, considering that most CLEO students would never have been admitted to law school without the program."288 Some summer programs provide an opportunity for students to prove themselves, and strong perfornance is a condition of admission. ${ }^{289}$

284. DeFunis v. Odegaard, 416 U.S. 312, 331 (1974) (Douglas, J., dissenting).

285. An astounding number of highly talented students do not attend college at all. Arthur Okun notes, "Among high school graduates with equal academic ability, the proportion going on to college averages nearly 25 percentage points lower for males (and nearly 35 for feinales) in the bottom socioeconomic quarter of the population than in the top quarter." OKUN, supra note 248, at 81 .

286. William Raspberry, High Expectations at Georgia Tech, WASH. POST, July 1, 1994, at A25.

287. Id.

288. Leshe G. Espinoza, Empowerment and Achievement in Minority Law Student Support Programs: Constructing Affirmative Action, 22 U. MrcH. J.L. REF. 281, 294 n.55 (1989) (citing Portia Hamlar, Minority Tokenism in American Law Schools, 26 How. L. I. 443, 543 (1983)). On the success of CLEO, see NAIRN, supra note 167, at 112-13; Eulius Simien, The Law School Admission Test as a Barrier to Almost Twenty Years of Affirmative Action, 12 T. MARSHALL L. REv. 359, 383-84 (1987). Whether applied to class-based or race-based affirmative action, CLEO programs make sense as a way of increasing chances of success and reducing stigma.

289. Espinoza, supra note 288, at 285 (noting that four schools use such a policy). 
Other summer programs, such as those at Texas Tech University School of Law and Wayne State University Law School, allow minority students to take one or two first-year classes so that they will have a more manageable, reduced first-year course load when the other students arrive. ${ }^{290}$

In the employment arena, some job traming programs have proven effective. ${ }^{291}$ And while critics rightly point to the failure of many remedial education and training prograins, such programs have not shown greater success, im large measure, because those same critics have effectively starved the programs of funding. ${ }^{292}$

\section{The Future Of Race-Based Affirmative Action}

Even if one adopts a class-based affirmative action prograin, there will still be a continuing need to address questions of race and gender. President Clinton is correct to focus attention on the undeniable fact that discrimination continues to do great harm to women and people of color. A number of audit studies have shown, for instance, that when equally qualified white and black testers apply for a job, the whites are more likely to be hired. ${ }^{293}$

Therefore, along with class-based programs, current antidiscriminatory protections, including the Civil Rights Act of 1991, would remain in effect. Aggressive enforcement of nonpreferential antidiscriminatory mechanisms currently on the books, and the improvement of antidiscrimination statutes where necessary, would be pursued. Funding for agencies that enforce antidiscriminatory measures should be increased to make up for the loss of firepower in the last fifteen years. ${ }^{294}$

Indeed, three powerful antidiscrimination tools already exist to address employment discrimination. First, civil suits can be brought in cases of intentional discrimination, with the possibility of punitive damages. ${ }^{295}$ Second, statistics-based suits may be brought under the Civil Rights Act of 1991 when an employment practice has a disparate impact and cannot be defended by business necessity. The disparate impact rule-unlike racial preferences-has broad support: the Griggs decision was unanimous, and the final 1991 Civil Rights Act had only a few

290. Id. at 284.

291. Cyrena N. Pondrom, The Carrot and the Stick: Twin Approaches to Achieving Minority Employment Equality, in ETHNicity, LAW AND THE SOCIAL GOOD 74, 80-84 (Winston A. Van Horne \& Thomas V. Tonnesen eds., 1983).

292. Nicholas lemann, The Promised Land: The Great Black Migration and How in Changed America 219 (1991).

293. AfFirmative Action Review, supra note 3, at 21-23.

294. See supra note 129.

295. Punitive damages for racial discrimination are unlimited. The Civil Rights Act of 1991 created the right to punitive damages in gender discrimination cases but capped the amount that may be awarded. 42 U.S.C. $\S 1981$ a(b)(3) (1994). 
dissenting votes. ${ }^{296}$ Third, "old style" affirmative action (broadening the pool of applicants) is an important tool to fight hiring through the "old boy" network. Unlike preferential affirmative action, ensuring that a broad pool of applicants is mterviewed is actually antidiscriminatory across the board, since it serves to remove informational barriers to pools of applicants who might not otherwise know of a particular employment opportunity.

Furthermore, the switch from race-based to class-based preferences would not have to happen all at once, and civil rights groups might negotiate a phaseout of race-based affirmative action over a certain number of years, combined with an assurance that class-based programs would be aggressively pursued. ${ }^{297}$

For the most part, however, class-based preferences are designed to supplant, rather than supplement, race-based preferences. Contrary to President Clinton's view, affirmative action was not designed as a prophylactic against future discrimination, but rather as a remedy for the present-day legacy of past discrimination. ${ }^{298}$ Since class-based preferences will more effectively remedy this legacy, and since antidiscriminatory measures will combat future discrimination, race-based programs will be needed in only those rare cases where the facts justify an extreme remedy, such as where a recalcitrant employer simply does not obey injunctions agaimst future discrimination.

296. The vote in the Senate for the 1991 Civil Rights Act was 93-5. 137 Cong. Rec. S15,503 (1991).

297. This arrangement would not be meaningless for opponents of affirmative action, since preferences based on diversity have no end in sight. Likewise, in order to ensure that the trade is a good one, proponents of racial affirmative action might negotiate for a legislative hammer: if a shortfall in funding of class-based affirmative action occurs, universities and employers would be able to retum to race-based decision making. This would help to reassure proponents of affirmative action that the deal is a real one-not an unfunded shell, and that the programs would in fact be funded lest the appropriators risk the wrath of voters who do not want to see a retum to race-based preferences.

298. The President claims that opponents of affirmative action want to rely on inherently flawed antidiscriminatory legislation that requires that individual plaintiffs prove racial discrimination on a case-by-case basis. The Affirmative Action Review, for example, says antidiscrimination laws are inadequate because they are "often dependent upon clear 'smoking gun' evidence of overt bias or bigotry, whereas prejudice can take on myriad subtle, yet effective, forms." AfFirmative Action REviEw, supra note 3 , at 8.

But, in fact, current antidiscrimination law is often not dependent on such "smoking gun" evidence. There is a middle step between requiring solid proof of individual cases of discrimination, and requiring racial preferences and set asides that strive for proportional representation (Clinton's approach). The middle ground is embodied in disparate impact law, first laid out in Griggs v. Duke Power Co., 401 U.S. 424 (1971), and codified in the Civil Rights Act of 1991.

Under disparate impact analysis, which applies to both employment and education, if a work force or university is racially imbalanced, there is reason to be suspicious of discrimination, either conscious or unconscious. But the presumption is rebuttable: an employer can make a showing that the imbalance has a race-neutral and valid cause, based on "business necessity." This compromise provides an effective tool against subtle discrimination without actually requiring preferences. 
The end goal, then, would be a world without racial preference, except in those limited instances where such preferences are justified as a narrow remedy for docunented discrimination of the kind envisioned in Croson and Adarand. The new regime would effectively overturn Bakke (which legitimated racial preferences to achieve educational diversity), ${ }^{299}$ Weber and Johnson (which legitimated voluntary racial preferences when past discrimination is presumed and has not been documented), ${ }^{300}$ and Executive Order No. 11,246 (which effectively requires mild preferences, even when no past discrimination has been documented). ${ }^{301}$ Even though remedies meeting the standards of Croson and Adarand remain politically unpopular, they present the very

299. On the other hand, as Justice Douglas noted in DeFunis, if an individual could prove that he suffered from egregious racial discrimination that influenced performance, the proven racial discrimination might properly be considered a relevant disadvantage. 416 U.S. at 340-41.

300. In addition, race would not be permitted as a bona fide occupational qualification except in very narrow circumstances, such as when an all-white police force hires a minority officer to do undercover work in a racially homogenous gang.

In one sense, then, the class-based approach goes further than the Dole legislation in rooting out racial preference. In the private sector, a literal interpretation of the Civil Rights Act of 1964 would be restored-discrimination based on race, whether anti-black or anti-white, would be illegal in almost every case. The exception would involve those extremely rare cases of egregious discrimination rising to the level found among the Alabama Troopers in the Paradise case. See United States v. Paradise, 480 U.S. 149 (1987). The Weber loophole-which allows employers to provide preferences with no evidence of discrimination, and to shift the burden of remedy from themselves to prospective white employees-would be closed. See United Stcelworkers v. Weber, 443 U.S. 193 (1979). Only those employers who admit to, and document, actual discrimination, would be permitted to employ racial preference as a truly temporary reınedy. Likewise, racial preferences to create "diversity" in employment or higher education would be made illegal. Bakke would be overturned legislatively.

On the other hand, the class-based approach would not go as far as Dole to the extent that it allows federal racial preferences that genuinely meet the strict scrutiny test of Adarand. See supra Part II.B (discussing the Dole proposal). Again, Paradise is emblematic of the type of evidence required. Where Dole would eliminate even those highly justified racial preferences, temporary remedies for proven discrimination must be permitted under the class-based alternative. As the frequency of egregious discrimination diminishes, the number of such narrow remedies should decline.

301. Existing voluntary consent decrecs negotiated under Weber would be reopened to see whether the new tougher standard for racial preferences is met. Even in the absence of class-based affirmative aetion, Drew Days has argued that the Weber standard is far too weak; he says employers and unions should be required to make "a showing of past discrimination." Days, supra note 99 , at 462.

The same rule could apply to the universities in the 16 states that agreed to preferences under the Adams litigation. See Adams v. Richardson, 356 F. Supp. 92 (D.D.C. 1973), aff'd in part and modified in part, 480 F.2d 1159 (D.C. Cir. 1973), dismissed sub nom. Women's Equity Action League v. Cavazos, 906 F.2d 742 (D.C. Cir. 1990). Universities would no longer be permitted simply to incorporate the provisions of consent decrces adopted by other universities (as Duke University has done with the consent decree entered into by the University of North Carolina) without their own findings of discrimination. See D'SouzA, supra note 84, at 158-63. 
strongest case for compensatory justice, and, in practice, will occur only infrequently. ${ }^{302}$

\section{CONCLUSION}

The current political debate over affirmative action is highly frustrating in its presentation of polar approaches. Senator Dole is right to criticize President Clinton for clinging to a policy that promotes equal group results, under the code words of diversity and inclusion. In turn, President Clinton is right to criticize Dole for failing to provide children boru into poor circumstances the kind of genume equal opportunity that requires aggressive public action. If genuine equal opportunity is the agreed-upon end, class-based preference is the obvious remedy. Americans still oppose preferences $60 \%$ to $20 \%$. See Starr, supra note 245 , at 9 . 


$$
\text { . }
$$

$$
\text { , }
$$

